\title{
Brown carbon aerosol in the North American continental troposphere: sources, abundance, and radiative forcing
}

\author{
J. Liu ${ }^{1, \text { a }}$, E. Scheuer ${ }^{2}$, J. Dibb ${ }^{2}$, G. S. Diskin ${ }^{3}$, L. D. Ziemba ${ }^{3}$, K. L. Thornhill ${ }^{3}$, B. E. Anderson ${ }^{3}$, A. Wisthaler ${ }^{4}$, \\ T. Mikoviny ${ }^{5}$, J. J. Devi ${ }^{6}$, M. Bergin ${ }^{6}$, A. E. Perring ${ }^{7,8}$, M. Z. Markovic ${ }^{7,8}$, J. P. Schwarz ${ }^{7,8}$, P. Campuzano-Jost ${ }^{8,9}$, \\ D. A. Day ${ }^{8,9}$, J. L. Jimenez ${ }^{8,9}$, and R. J. Weber ${ }^{1}$ \\ ${ }^{1}$ School of Earth and Atmospheric Sciences, Georgia Institute of Technology, Atlanta, GA 30332, USA \\ ${ }^{2}$ Institute for the Study of Earth, Oceans, and Space, University of New Hampshire, Durham, NH 03824, USA \\ ${ }^{3}$ NASA Langley Research Center, Hampton, VA 23681, USA \\ ${ }^{4}$ Institute of Ion Physics and Applied Physics, University of Innsbruck, Innsbruck, Austria \\ ${ }^{5}$ Oak Ridge Associated Universities (ORAU), Oak Ridge, TN 37830, USA \\ ${ }^{6}$ School of Civil \& Environmental Engineering, Georgia Institute of Technology, Atlanta, GA, USA \\ ${ }^{7}$ Chemical Sciences Division, Earth System Research Laboratory, National Oceanic and Atmospheric Administration, \\ Boulder, Colorado 80305, USA \\ ${ }^{8}$ Cooperative Institute for Research in Environmental Sciences, University of Colorado, Boulder, CO 80309, USA \\ ${ }^{9}$ Department of Chemistry and Biochemistry, University of Colorado, Boulder, CO 80309, USA \\ ${ }^{a}$ now at: Atmospheric Sciences and Global Change Division, Pacific Northwest, National Laboratory, Richland, \\ WA 99352, USA
}

Correspondence to: R. J. Weber (rodney.weber@eas.gatech.edu)

Received: 22 January 2015 - Published in Atmos. Chem. Phys. Discuss.: 3 March 2015

Revised: 9 June 2015 - Accepted: 18 June 2015 - Published: 16 July 2015

\begin{abstract}
Chemical components of organic aerosol (OA) selectively absorb light at short wavelengths. In this study, the prevalence, sources, and optical importance of this socalled brown carbon $(\mathrm{BrC})$ aerosol component are investigated throughout the North American continental tropospheric column during a summer of extensive biomass burning. Spectrophotometric absorption measurements on extracts of bulk aerosol samples collected from an aircraft over the central USA were analyzed to directly quantify $\mathrm{BrC}$ abundance. $\mathrm{BrC}$ was found to be prevalent throughout the 1 to $12 \mathrm{~km}$ altitude measurement range, with dramatic enhancements in biomass-burning plumes. $\mathrm{BrC}$ to black carbon (BC) ratios, under background tropospheric conditions, increased with altitude, consistent with a corresponding increase in the absorption Ångström exponent (AAE) determined from a three-wavelength particle soot absorption photometer (PSAP). The sum of inferred BC absorption and measured $\mathrm{BrC}$ absorption at $365 \mathrm{~nm}$ was within $3 \%$ of the measured PSAP absorption for background conditions and $22 \%$ for biomass burning. A radiative
\end{abstract}

transfer model showed that $\mathrm{BrC}$ absorption reduced top-ofatmosphere (TOA) aerosol forcing by $\sim 20 \%$ in the background troposphere. Extensive radiative model simulations applying this study background tropospheric conditions provided a look-up chart for determining radiative forcing efficiencies of $\mathrm{BrC}$ as a function of a surface-measured $\mathrm{BrC}: \mathrm{BC}$ ratio and single scattering albedo (SSA). The chart is a first attempt to provide a tool for better assessment of brown carbon's forcing effect when one is limited to only surface data. These results indicate that $\mathrm{BrC}$ is an important contributor to direct aerosol radiative forcing.

\section{Background}

Carbonaceous components of atmospheric aerosols are known to affect climate through direct scattering and absorption of solar radiation. The most prevalent carbonaceous aerosol component is the organic aerosol (OA) fraction, which until recently was assumed to only scatter light 
and act to cool the climate (Koch et al., 2007; Myhre et al., 2008). The black carbon (BC) fraction efficiently absorbs light and substantially warms the atmosphere (Bond et al., 2013). Globally, BC forcing is ranked the third most important anthropogenic climate-warming agent after carbon dioxide and methane (IPCC, 2013), considering both direct and indirect effects. Recent studies have shown, however, that components of OA also contribute to light absorption (e.g., Yang, et al., 2009; Zhang et al., 2011, 2013) and that their influence on climate may be substantial (Bahadur et al., 2012; Chung et al., 2012; Feng et al., 2013; Park et al., 2010). These compounds are referred to as brown carbon (BrC hereafter) because they tend to absorb light most efficiently at short wavelengths.

A variety of studies have investigated the sources for $\mathrm{BrC}$. Primary $\mathrm{BrC}$ is known to be emitted directly from incomplete combustion of fossil or biomass fuels (Hoffer et al., 2006; Lukacs et al., 2007; Andreae and Gelencsér, 2006), and secondary organic aerosol (SOA) formed from combustion emissions may also be brown (Saleh et al., 2013; Zhang et al., 2013). Laboratory studies find that light-absorbing secondary compounds (chromophores) can be formed by a variety of mechanisms, including aromatic-SOA production under high levels of nitrogen oxides $\left(\mathrm{NO}_{x}\right)$, and through various aqueous-phase reactions, such as lignin (Hoffer et al., 2006) and isoprene oxidation (Limbeck et al., 2003), or form lightabsorbing oligomers from reactive uptake of isoprene epoxydiols (Lin et al., 2014). They can also be formed from reactions of carbonyls (e.g., glyoxal, methylglyoxal) in acidic solutions (Sareen et al., 2010), with amino acids (de Haan et al., 2009), methyl amines (de Haan et al., 2009), or ammonium salts (Sareen et al., 2010). The concentration of solutes during droplet evaporation can also enhance $\mathrm{BrC}$ formation (Zarzana et al., 2012). While BrC can be lost by wet and dry deposition, analogous to OA, atmospheric aging of aerosols may also lead to a loss of $\mathrm{BrC}$ due to photo bleaching (Lee et al., 2014; Zhong and Jang, 2014; Forrister et al., 2015).

$\mathrm{BrC}$ can be difficult to identify with aerosol optical instruments. Lack and Langridge (2013) suggested that the use of an observed wavelength dependence of light absorption, described by the absorption Ångström exponents (AAE), to predict $\mathrm{BrC}$ absorption leads to substantial uncertainties. Difficulties arise because optical instruments cannot measure $\mathrm{BrC}$ independently of $\mathrm{BC}$. Typically, $\mathrm{BrC}$ is determined based on differences between the observed absorption at low wavelengths, where $\mathrm{BrC}$ absorption is effective, to what is expected from $\mathrm{BC}$ alone. Both factors in the difference calculation are uncertain. There have also been attempts to decouple the effects of $\mathrm{BC}$ absorption (including enhancement due to internal mixing - lensing) and $\mathrm{BrC}$ absorption by integrating measurements with Mie theory calculations (e.g., Lack et al., 2012; Saleh et al., 2014). However, one of the main uncertainties is related to what BC absorption should be, independent of other absorbers. Some studies indicate that BC mixing state with non-absorbing materials can lead to sub- stantial shifts in AAE relative to pure BC (Lack and Langridge, 2013), making it difficult to attribute enhanced light absorption at low wavelengths to $\mathrm{BC}$ mixing state or $\mathrm{BrC}$, if based solely on AAE.

A more definitive and sensitive approach for identifying $\mathrm{BrC}$ is possible by directly measuring chromophores in aerosol solution extracts, since the method can isolate $\mathrm{BrC}$ from other absorbers (BC and mineral dust) and long-path absorption cells provide a measurement with high sensitivity. Studies have shown that $>85 \%$ of the organic aerosols could be extracted by methanol (e.g., Chen and Bond, 2010; Cheng et al., 2015). These direct measurements of $\mathrm{BrC}$ show that it is ubiquitous. $\mathrm{BrC}$ has been shown to be strongly linked to biomass burning and humic-like substances (HULIS) throughout Europe (Lukacs et al., 2007). In the southeastern USA, $\mathrm{BrC}$ has been found in rainwater from continental sources (Kieber et al., 2006), while $\mathrm{BrC}$ in $\mathrm{PM}_{2.5}$ was associated with biomass burning in winter and summer, along with possible contributions from SOA formation (Hecobian et al., 2010; Zhang et al., 2012; Washenfelder et al., 2015).

Chromophores in the ambient aerosol that produce the observed BrC optical properties are not well characterized. Zhang et al. (2013) identified a number of water-soluble nitro-aromatic compounds responsible for $\mathrm{BrC}$ in Los Angeles SOA, but they only accounted for $\sim 4 \%$ of observed $\mathrm{BrC}$ absorption at $365 \mathrm{~nm}$. 4-Nitrocatechol $\left(\mathrm{C}_{6} \mathrm{H}_{5} \mathrm{NO}_{4}\right)$ was identified as the largest contributor at roughly $1.4 \%$. Similar nitro-aromatic chromophores have been identified in fogs (Desyaterik et al., 2013) and aerosols (Mohr et al., 2013) impacted by biomass burning.

Although studies of $\mathrm{BrC}$ based on aerosol extracts have been used to investigate the sources, extent, and chemistry of fine particulate $\mathrm{BrC}$, it is difficult to use this method to assess optical properties of BrC-containing particles. To estimate optical properties from solution data, Liu et al. (2013) used size-resolved measurements of aerosol extract light absorbance from several sites to estimate light absorption $\left(b_{\text {ap }}\right)$ by $\mathrm{BrC}$-containing particles, assuming that the $\mathrm{BrC}$ was externally mixed with other absorbers. In this study, we apply these results to aircraft-based filter measurements and use the direct measurements of chromophores in solutions to estimate the extent and sources of $\mathrm{BrC}$ throughout the US continental troposphere (up to $\sim 12 \mathrm{~km}$ altitude). A closure analysis is performed comparing the sum of light absorption at $365 \mathrm{~nm}$ from $\mathrm{BC}$ and $\mathrm{BrC}$ to measurements extrapolated from a three-wavelength particle soot absorption photometer (PSAP), averaged over filter sampling intervals, to assess our method for inferring $\mathrm{BC}$ and $\mathrm{BrC}$. The importance of $\mathrm{BrC}$ is then determined through a radiative transfer model using altitude-resolved $\mathrm{BC}$ and $\mathrm{BrC}$ data to delineate absorbing aerosol forcing in the continental troposphere from these two components. Since column measurements are rare, the average background tropospheric vertical profile measured in this study is used to create a chart that allows for estimation of $\mathrm{BrC}$ top-of-atmosphere (TOA) forcing based on sur- 

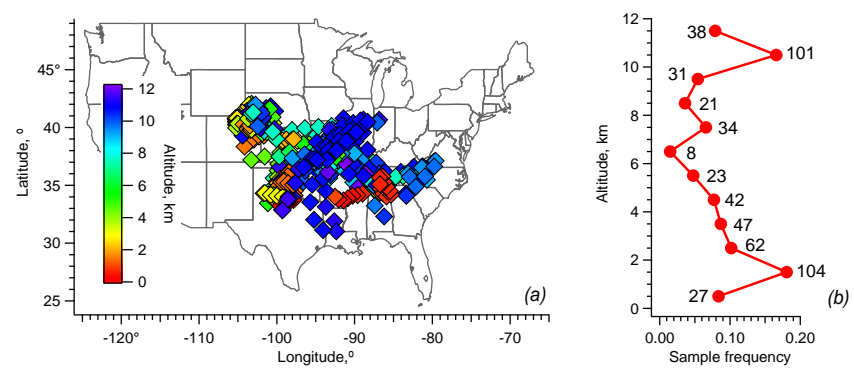

Figure 1. (a) Filter collection sampling locations, color-coded by altitude, and (b) sampling frequency versus altitude for the complete DC3 mission, with number of filters for each altitude bin given.

face measurements of aerosol optical properties and aerosol optical depth (AOD).

\section{Method}

\subsection{NASA DC-8 research aircraft measurements during the DC3 campaign}

Filters were collected from the NASA DC-8 research aircraft, based out of Salina, KS, between May and June 2012 as part of the Deep Convective Clouds and Chemistry (DC3) campaign (Barth et al., 2014). The study area focused on the central USA and filter samples were obtained from near-surface to an altitude of roughly $12 \mathrm{~km}$ a.s.l. (pressure altitude). Figure 1a shows the locations of filter sampling periods during the study, color-coded by altitude.

\subsection{Filter sampling, extraction, and analysis}

The filter sampling system captured particles nominally smaller than $4.1 \mu \mathrm{m}$ aerodynamic diameter (McNaughton et al., 2007) onto $1 \mu \mathrm{m}$ pore, $90 \mathrm{~mm}$ diameter, Teflon (EMD Millipore) filters. Sampling was generally done during level flight legs with typically $5 \mathrm{~min}$ integration times. In total, 609 filter samples were obtained from 22 flights, along with 2 field blanks per flight. Data were corrected by subtraction of the average blank for each flight. Over the course of the study, filters were not uniformly collected over the measurement column. Figure $1 \mathrm{~b}$ shows the filter sampling frequency (number of filters collected/total filters) as a function of altitude.

Filters were extracted first in $15 \mathrm{~mL}$ of high-purity water $(18.3 \mathrm{M} \Omega)$ by $30 \mathrm{~min}$ of sonication. The liquid extracts were then filtered via a $25 \mathrm{~mm}$ diameter $0.45 \mu \mathrm{m}$ pore syringe filter (Fisher Scientific, Fisherbrand ${ }^{\mathrm{TM}}$ Syringe Filters) to remove insoluble components. Water extracts were transferred into a liquid waveguide capillary cell coupled to a total organic carbon (LWCC-TOC) analyzer. The combined system quantifies the water-soluble UV-vis (nominally 200 to $800 \mathrm{~nm}$ wavelength range) light absorption spectra (re- ferred to here as $\left.\mathrm{H}_{2} \mathrm{O} \_\mathrm{Abs}(\lambda)\right)$ and water-soluble organic carbon (WSOC) mass following the method by Hecobian et al. (2010). (See Table 1 for a list of acronyms.) The limit of detection (LOD) was determined as 3 times the standard deviation (SD) of field blanks. At $365 \mathrm{~nm}$ the LOD of the solution light absorption measurement $\left(\mathrm{H}_{2} \mathrm{O} \_\mathrm{Abs}(365)\right)$ was $0.031 \mathrm{M} \mathrm{m}^{-1}$, whereas the WSOC LOD is estimated at $0.084 \mu g C ~ m^{-3}$. Measurement uncertainties are estimated at $20 \%$ for $\mathrm{H}_{2} \mathrm{O} \_\mathrm{Abs}(365)$ and $9 \%$ for WSOC, based on uncertainties and variability in water blanks, field blanks, standards, and duplicate measurements.

Following water extraction, the extraction vial and filter were drained and dried by inverting; then the filter was re-extracted in $15 \mathrm{~mL}$ of methanol (VWR International, A.C.S. Grade) following the same procedure as the water extract; however, in this case only the UVvis absorption spectra were measured. The estimated LOD for methanol-soluble light absorption at a wavelength of $365 \mathrm{~nm}$ (MeOH_Abs(365)) is $0.11 \mathrm{M} \mathrm{m}^{-1}$ with an uncertainty of $27 \%$. Here, total solution absorption due to $\mathrm{BrC}$ (Total_Abs $(\lambda)$ ) is determined from the sum of water-soluble and methanol-extracted absorption from the sequential extraction process, under the assumption that this process dissolves all chromophores (Chen and Bond, 2010) (Total_Abs(365) uncertainty is roughly $\pm 34 \%$ ). Tests with filters loaded with ambient particles from urban Atlanta show that the methanol extraction, by itself, tends to also include most water-soluble compounds and that the sequential extraction is comparable to methanol extraction alone; the sum of light absorption from extractions of water plus methanol in series was within $\sim 10 \%$ of just methanol extraction (sample number $=18$ ).

\subsection{Online measurements}

\subsubsection{Gases}

A number of gases were used in this study as emissions tracers. Biomass burning was identified using acetonitrile $\left(\mathrm{CH}_{3} \mathrm{CN}\right)$ and carbon monoxide $(\mathrm{CO})$. Acetonitrile was measured via proton transfer reaction-mass spectrometer (PTRMS) (uncertainty of $\pm 20 \%$ ) and CO by a Diode laser spectrometer (uncertainty of $\pm 2 \%$ or $2 \mathrm{ppbv}$ ).

\subsubsection{Aerosols}

Particle light absorption coefficients $\left(b_{\mathrm{ap}}\right)$ were measured with a particle soot absorption photometer (PSAP; Radiance Research) at wavelengths of 470, 532, and $660 \mathrm{~nm}$. The inlet had an intrinsic $50 \%$ cut size of $4.1 \mu \mathrm{m}$, consistent with the filter collection, and the sample air was dried (relative humidity (RH) typically less than $40 \%$ ). As a filter-based optical instrument, where particle absorption is determined from light attenuation through a filter being loaded with particles, the PSAP suffers from various artifacts (Bond et al., 1999; 
Table 1. Nomenclature.

\begin{tabular}{|c|c|}
\hline PSAP & Particle soot absorption photometer \\
\hline$b_{\mathrm{ap}}$ & Light absorption coefficient for fine particles $\left(\mathrm{M} \mathrm{m}^{-1}\right)$ \\
\hline $\mathrm{BC}$ & Black carbon \\
\hline $\mathrm{BrC}$ & Brown carbon \\
\hline WSOC & Water-soluble organic carbon $\left(\mu \mathrm{gC} \mathrm{m}{ }^{-3}\right)$ \\
\hline OA & Organic aerosol $\left(\mu \mathrm{gm}^{-3}\right)$ \\
\hline AAE & Absorption Ångström exponent \\
\hline $\mathrm{AAE}_{\mathrm{BrC}}$ & Absorption Ångström exponent for brown carbon from solution data \\
\hline $\mathrm{AAE}_{\mathrm{BC}}$ & Absorption Ångström exponent for black carbon \\
\hline AAEPSAP & Absorption Ångström exponent based on the PSAP data \\
\hline$A(\lambda)$ & Light absorbance measured by the spectrophotometer (unitless) \\
\hline $\operatorname{Abs}(\lambda)$ & Light absorption measured in a solution at wavelength $\lambda\left(\mathrm{M} \mathrm{m}^{-1}\right)$ \\
\hline $\mathrm{H}_{2} \mathrm{O} \_\mathrm{Abs}(\lambda)$ & Light absorption measured in water extract at wavelength $\lambda\left(\mathrm{M} \mathrm{m}^{-1}\right)$ \\
\hline $\mathrm{MeOH} \_\mathrm{Abs}(\lambda)$ & Light absorption measured in methanol extract at wavelength $\lambda\left(\mathrm{M} \mathrm{m}^{-1}\right)$ \\
\hline Total_Abs $(\lambda)$ & $\begin{array}{l}\text { Sum of } \mathrm{H}_{2} \mathrm{O} \_\mathrm{Abs}(\lambda) \text { and } \mathrm{MeOH} \_\mathrm{Abs}(\lambda) \text { for a filter extracted sequentially using the two solvents (water then } \\
\text { methanol). }\end{array}$ \\
\hline$b_{\mathrm{ap}, \mathrm{H}_{2} \mathrm{O} \_\mathrm{BrC}}(\lambda)$ & $\begin{array}{l}\text { Mie predicted fine particle brown carbon absorption from water extracts }\left(\mathrm{M} \mathrm{m}^{-1}\right) \text {, wavelength is specified in } \\
\text { text. }\end{array}$ \\
\hline$b_{\text {ap, Total_BrC }}(\lambda)$ & $\begin{array}{l}\text { Mie predicted fine particle brown carbon absorption from the sum of water and methanol extracts }\left(\mathrm{M} \mathrm{m}^{-1}\right) \text {, } \\
\text { wavelength is specified in text. }\end{array}$ \\
\hline$b_{\mathrm{ap}, \operatorname{PSAP}}(\lambda)$ & Light absorption coefficient of fine particles at wavelength $\lambda\left(\mathrm{M} \mathrm{m}^{-1}\right)$ determined from the PSAP data \\
\hline$b_{\mathrm{ap}, \mathrm{BC} 1}(\lambda)$ & $\begin{array}{l}\text { Light absorption coefficient of } \mathrm{BC} \text { at wavelength } \lambda\left(\mathrm{M} \mathrm{m}^{-1}\right) \text {, estimated from PSAP absorption at } 660 \mathrm{~nm} \text {, as- } \\
\text { suming non-BC light absorbers are minimal at } 660 \mathrm{~nm} \text { and an tAAE } \mathrm{BC} \text { of } 1\end{array}$ \\
\hline$b_{\mathrm{ap}, \mathrm{BC} 2}(\lambda)$ & $\begin{array}{l}\text { Light absorption coefficient of BC at wavelength } \lambda\left(\mathrm{M} \mathrm{m}^{-1}\right) \text {, estimated using a mass absorption cross section } \\
\text { of } 7.5 \mathrm{~m}^{2} \mathrm{~g}^{-1} \text { at } 550 \mathrm{~nm} \text { and an } \mathrm{AAE} \mathrm{BC}_{\mathrm{BC}} \text { of } 1\end{array}$ \\
\hline$b_{\mathrm{ap} 2}(\lambda)$ & $\begin{array}{l}\text { Light absorption coefficient of fine particles at wavelength } \lambda\left(\mathrm{M} \mathrm{m}^{-1}\right) \text { determined from } b_{\mathrm{ap}, \mathrm{BC} 2}(660) \text { and } \\
\text { AAEPSAP }\end{array}$ \\
\hline MAC & Mass absorption cross section \\
\hline SZA & Solar zenith angle \\
\hline TOA & Top of atmosphere \\
\hline a.s.l. & Above sea level \\
\hline SD & Standard deviation \\
\hline
\end{tabular}

Petzold et al., 2005). This includes multiple scattering by the filter fibers and by aerosols embedded on or within the filter; the latter increases with filter loading. Reported PSAP $b_{\text {ap }}$ data were adjusted using Virkkula (2010). Based on the operation of the instrument, the PSAP absorption coefficients are estimated to have an uncertainty of $20 \%$ or $0.2 \mathrm{M} \mathrm{m}^{-1}$, whichever is larger. Artifacts that depend on aerosol composition, however, may increase this uncertainty (Lack et al., 2008). All PSAP data used in the following analyses have been averaged to filter sampling times.

Refractory black carbon ( $\mathrm{rBC}$; here referred to just as $\mathrm{BC}$ to minimize confusion with $\mathrm{BrC}$ ) mass concentrations were measured with a SP2 (Single Particle Soot Photometer) and corrected to account for accumulation-mode BC at sizes outside the detection range of the instrument (Schwarz et al., 2008). The instrument was calibrated with fullerene soot (Alfa Aesar Lot \#F12S011), the accepted calibration material for the instrument (Baumgardner et al., 2012). Estimated uncertainty is $30 \%$ from flow and BC mass calibrations and aspiration efficiency. OA was measured with a high-resolution time-of-flight Aerodyne aerosol mass spectrometer (AMS) (DeCarlo et al., 2006). The AMS was operated with a setup similar to that described in Dunlea et al. (2009) and using a pressure-controlled inlet (Bahreini et al., 2008). The AMS collection efficiency was estimated using the composition-dependent formulation of Middlebrook et al. (2011) as implemented in the standard AMS data analysis software (Sueper, 2015), and applied with a 1 min time resolution to reduce the effect of high-frequency noise. The AMS uncertainty for OA $(2 \sigma=38 \%)$ is estimated as described in Bahreini et al. (2009) and Middlebrook et al. (2012) and is dominated by the uncertainty in collection efficiency and relative ionization efficiency of OA. In the following analysis, online data were averaged to filter sampling times and included in the analysis if the online data covered greater than $75 \%$ of the sampling time. All aircraft data are blank corrected and reported at standard temperature and pressure (273 K and $1013 \mathrm{mb}$ ).

The ambient light scattering coefficients $\left(b_{\mathrm{sp}}\right)$, used in the subsequent radiative transfer model, were measured by a TSI 
integrating nephelometer at wavelengths of 450, 550, and $700 \mathrm{~nm}$. The inlet cut point was the same as other instruments (aerodynamic diameter of $4.1 \mu \mathrm{m}$ ). Scattering coefficients at three wavelengths will be first averaged over the filter sampling period, if more than $75 \%$ of the period is covered by measurements. The averaged scattering coefficients were then extended to other wavelengths based on a scattering Ångström exponent (SAE) by Eqs. (1) and (2).

$$
\begin{aligned}
\mathrm{SAE} & =-\frac{\ln \left(b_{\mathrm{sp}}(700)\right)-\ln \left(b_{\mathrm{sp}}(450)\right)}{\ln (700)-\ln (450)} \\
b_{\mathrm{sp}}(\lambda) & =b_{\mathrm{sp}}(550) \cdot\left(\frac{\lambda}{550}\right)^{-\mathrm{SAE}}
\end{aligned}
$$

Excluding biomass-burning plumes, the study mean $\pm \mathrm{SD}$ SAE was $1.27 \pm 0.74$, scattering data were reported to have a $10 \%$ uncertainty for measurements at all three wavelengths; therefore, the combined uncertainty in estimated scattering coefficients at various wavelengths, based on Eqs. (1) and (2), was estimated at roughly $20 \%$.

\section{Results}

In the following analysis, we first use data on light absorption of the aerosol extracts to investigate sources and distributions of BrC. Following this, the solution data are converted to estimates of $\mathrm{BrC}$ aerosol absorption coefficients and the optical effects of $\mathrm{BrC}$ are investigated.

\subsection{Identifying biomass-burning plumes}

During the DC3 campaign, 2 out of 22 aircraft flights were specifically targeted to investigate biomass-burning emissions, and in 6 other flights at least one biomass-burning plume was encountered. For this work, the data are simply delineated between clearly evident biomass-burning sampling periods and all else, the latter being referred to as background tropospheric conditions. To identify biomass-burning plumes, $\mathrm{CO}$ and $\mathrm{CH}_{3} \mathrm{CN}$ were used as tracers following the method of de Gouw et al. (2004). First, enhancements in CO in time-series plots were identified. For these episodes, if $r^{2}$ values for $\mathrm{CO}$ and $\mathrm{CH}_{3} \mathrm{CN}$ are higher than 0.5 , the plume will be designated as biomass burning. Identified biomassburning sampling periods are listed in Table 2. If greater than $75 \%$ of the filter sampling integration time is identified as a biomass-burning plume, it will be characterized as biomass burning. By this criterion roughly $12 \%$ of collected filters were identified as biomass burning. Filters not identified are referred to as background measurements, but may still have been influenced, to some extent, by biomass burning due to small-duration plume intercepts. Residual impacts from dispersed biomass-burning emissions may also account for some fraction of the ambient aerosol throughout the troposphere during this study. However, the majority of filters were collected under what could be considered more typical
Table 2. Periods of identified biomass-burning plumes.

\begin{tabular}{l}
\hline Time (UTC) \\
\hline 25 May 2012, 22:00-22:26 \\
26 May 2012, 21:20-21:40; 27 May 2012, 00:09-00:21 \\
06 June 2012, 21:27-21:37; 07 June 2012, 00:19-00:36 \\
11 June 2012, 16:24-16:57; 17:56-18:11; 21:56-22:06 \\
15 June 2012, 19:51-20:10 \\
16 June 2012, 21:18-21:26; 17 June 2012, 01:36-02:13 \\
17 June 2012; whole flight \\
22 June 2012; whole flight \\
\hline
\end{tabular}

continental tropospheric conditions, albeit during a summer of extensive burning.

\subsection{Study statistical summary}

A summary of the DC3 BrC solution measurements, together with other relevant species, is given in Table $3 . \mathrm{BrC}$ in filter extracts was observed throughout the study region, with over $85 \%$ of the data above the LOD.

Comparing with background conditions, biomass-burning plumes were notable by significantly higher $\mathrm{BrC}$ levels. Average $\mathrm{H}_{2} \mathrm{O} \_$Abs(365) in the identified biomass-burning plumes was $\overline{5}$ times higher than background conditions, while Total_Abs(365) was approximately 4 times higher. In contrast, the enhancements in other species were smaller; WSOC was only $\sim 1.3$, OA 2.8, and BC 2.6 times higher than background conditions. The differential enhancement of WSOC and $\mathrm{H}_{2} \mathrm{O} \_\mathrm{Abs}(365)$ or Total_Abs(365) indicates that biomass-burning aerosol is browner on a per mass basis (higher mass absorption efficiencies) than the background aerosol, as seen in other studies (Hecobian et al., 2010). These results confirm that biomass-burning is a strong source for both water- and methanol-soluble $\mathrm{BrC}$ and are consistent with studies using different methods to identify $\mathrm{BrC}$ and biomass burning (Lack et al., 2013).

The proportion of water- to methanol-soluble $\mathrm{BrC}$ was different in background versus biomass-burning plumes. In background air masses, the water-soluble $\mathrm{BrC}$ fraction was roughly 25 to $33 \%$ (i.e., $\mathrm{H}_{2} \mathrm{O} \_\mathrm{Abs}(365)$ : Total_Abs(365)), similar to previous studies (Zhang et al., 2013; Liu et al., 2013). However, the water-soluble $\mathrm{BrC}$ fraction was higher in biomass-burning plumes, where $\mathrm{H}_{2} \mathrm{O} \_\mathrm{Abs}(365)$ comprised $\sim 45 \%$ of the Total_Abs(365). These data suggest that primary smoke emissions contain or form more water- relative to methanol-soluble BrC compared to aged $\mathrm{BrC}$.

\subsection{Correlations}

Associations between various species in both the biomassburning plumes and under background conditions are investigated based on correlations. Results are summarized in Table 4. Correlations are shown for $\mathrm{H}_{2} \mathrm{O} \_\mathrm{Abs}(365)$ and To- 
Table 3. Statistical summary of observed species throughout all flights during DC3 separated into three categories: all samples, samples during identified biomass-burning events and samples for background conditions (periods when data could not be clearly identified as biomass burning). For statistical purposes, one-half the LOD value is substituted for data below LOD. All data have been merged to the nominally 5 min filter sampling time.

\begin{tabular}{|c|c|c|c|c|c|c|c|}
\hline $\begin{array}{l}\text { All } \\
\text { samples }\end{array}$ & LOD & $\begin{array}{r}\% \text { above } \\
\text { LOD }\end{array}$ & Mean & Median & SD & Min & $\operatorname{Max}$ \\
\hline WSOC $^{\mathrm{a}}$ & 0.084 & 95 & 1.24 & 0.81 & 1.83 & 0.042 & 31.37 \\
\hline $\mathrm{OA}^{\mathrm{b}}$ & 0.30 & 89 & 3.48 & 2.82 & 10.85 & 0.15 & 208.53 \\
\hline $\mathrm{BC}^{\mathrm{b}}$ & 0.01 & 84 & 0.069 & 0.036 & 0.189 & 0.005 & 3.75 \\
\hline $\mathrm{H}_{2} \mathrm{O} \_\mathrm{Abs}(365)^{\mathrm{c}}$ & 0.031 & 87 & 0.33 & 0.11 & 1.93 & 0.016 & 39.50 \\
\hline Total_Abs $(365)^{\mathrm{c}}$ & 0.11 & 86 & 0.94 & 0.44 & 3.89 & 0.055 & 67.19 \\
\hline \multicolumn{8}{|c|}{ Biomass-burning events } \\
\hline WSOC & 0.084 & 94 & 1.52 & 0.77 & 3.93 & 0.042 & 31.37 \\
\hline $\mathrm{OA}$ & 0.30 & 88 & 7.55 & 3.73 & 25.95 & 0.15 & 208.53 \\
\hline $\mathrm{BC}$ & 0.01 & 83 & 0.144 & 0.052 & 0.47 & 0.005 & 3.75 \\
\hline $\mathrm{H}_{2} \mathrm{O} \_\mathrm{Abs}(365)$ & 0.031 & 92 & 1.03 & 0.32 & 4.66 & 0.016 & 39.50 \\
\hline Total_Abs(365) & 0.11 & 93 & 2.37 & 0.86 & 8.67 & 0.055 & 67.19 \\
\hline \multicolumn{8}{|c|}{ Background conditions } \\
\hline WSOC & 0.084 & 95 & 1.19 & 0.82 & 1.28 & 0.042 & 10.68 \\
\hline $\mathrm{OA}$ & 0.30 & 93 & 2.69 & 2.01 & 2.69 & 0.15 & 12.79 \\
\hline $\mathrm{BC}$ & 0.01 & 88 & 0.056 & 0.035 & 0.060 & 0.005 & 0.399 \\
\hline $\mathrm{H}_{2} \mathrm{O} \_\mathrm{Abs}(365)$ & 0.031 & 86 & 0.20 & 0.10 & 0.53 & 0.016 & 7.52 \\
\hline Total_Abs(365) & 0.11 & 85 & 0.64 & 0.36 & 1.38 & 0.055 & 15.44 \\
\hline
\end{tabular}

a unit: $\mu \mathrm{gCm}{ }^{-3}$; ${ }^{b}$ unit: $\mu \mathrm{g} \mathrm{m}^{-3} ;{ }^{\mathrm{c}}$ unit: $\mathrm{M} \mathrm{m}^{-1}$

tal_Abs(365). Since, for background conditions, two-thirds to three-quarters of the $\mathrm{BrC}$ absorption is associated with the methanol extract, Total_Abs(365) correlations with various other species are driven primarily by the methanolsoluble $\mathrm{BrC}$ (for brevity, we do not show correlations for just the methanol-soluble $\mathrm{BrC}$ ). Note that for airborne measurements, temporal correlations imply spatial correlations between species.

For biomass-burning samples, species expected from the smoke plumes (e.g., CO, acetonitrile, OA, WSOC, BC, and PSAP $b_{\text {ap }}$ at all three wavelengths) are highly correlated with each other, and all are highly correlated with both $\mathrm{H}_{2} \mathrm{O} \_$Abs(365) and Total_Abs(365), consistent with a common source. The least correlated were WSOC and BC $(r=$ $0.70)$, and $\mathrm{H}_{2} \mathrm{O} \_\mathrm{Abs}(365)$ and $\mathrm{BC}(r=0.72)$, possibly because some fraction of the water-soluble compounds may be secondary and not as likely to be correlated with a primary component (BC).

In contrast, for background conditions there was a poor correlation between $\mathrm{H}_{2} \mathrm{O} \_\mathrm{Abs}(365)$ and Total_Abs(365) $(r=0.32)$ and they were correlated with a different set of species. $\mathrm{H}_{2} \mathrm{O} \_\mathrm{Abs}(365)$ was correlated mostly with the PSAP measurements of absorption $(r=0.66$ at $470 \mathrm{~nm})$ or with BC $(r=0.64)$, but not well correlated with WSOC $(r=0.34)$. But, $\mathrm{H}_{2} \mathrm{O} \_\mathrm{Abs}(365)$ was somewhat correlated with OA $(r=0.57)$ and acetonitrile $(r=0.57)$, suggesting that the water-soluble faction in the background troposphere could be more strongly related to primary emissions and possibly linked to aged biomass burning.

Total_Abs(365) was not well correlated with any of the other parameters in the background samples. This lack of correlation suggests that much of the background tropospheric BrC had undergone some form of processing or evolution (e.g., photobleaching). A similar situation is observed for WSOC, which was also not generally correlated with any of the other variables in Table 4. In a ground-based study, Liu et al. (2013) observed higher relative levels of water to methanol-soluble $\mathrm{BrC}$ near sources compared to aged aerosol, consistent with an aging process that preferentially depletes water-soluble fraction of $\mathrm{BrC}$. Other chemical processes are possible; e.g., Lin et al. (2014) showed that IEPOX-derived oligomers that absorb in the ultraviolet region are more soluble in methanol, suggesting the potential contribution of biogenic SOA especially in biogenicrich regions. However, a recent study showed that at a remote surface site in the southeast USA, significantly impacted by biogenic SOA, biomass-burning was the dominant $\mathrm{BrC}$ source (Washenfelder et al., 2015). Therefore, we believe aged biomass burning is the main source of the ubiquitous $\mathrm{BrC}$, but that biogenic SOA cannot be ruled out. 
Table 4. Pearson rank correlations $(r)$ for biomass-burning plumes and background conditions. Bold values above the matrix diagonal are from biomass-burning plumes (69 data points), while italic numbers below the matrix diagonal are from background conditions ( 334 data points). All data were averaged to filter sampling times.

\begin{tabular}{|c|c|c|c|c|c|c|c|c|c|c|}
\hline & WSOC & $\mathrm{H}_{2} \mathrm{O} \_\mathrm{Abs}(365)$ & Total_Abs(365) & $\mathrm{OA}$ & $\mathrm{CO}$ & $\mathrm{BC}$ & Acetonitrile & $b_{\text {ap,PSAP }}(470)$ & $b_{\text {ap,PSAP }}(532)$ & $b_{\text {ap,PSAP }}(660)$ \\
\hline WSOC & 1 & 0.99 & 0.97 & 0.96 & 0.93 & 0.70 & 0.97 & 0.75 & 0.75 & 0.75 \\
\hline $\mathrm{H}_{2} \mathrm{O} \_\mathrm{Abs}(365)$ & 0.34 & 1 & 0.98 & 0.98 & 0.94 & 0.72 & 0.98 & 0.7 & 0.78 & 0.78 \\
\hline Total_Abs(365) & 0.13 & 0.32 & 1 & 0.995 & 0.97 & 0.83 & 0.99 & 0.87 & 0.87 & 0.87 \\
\hline OA & 0.28 & 0.57 & 0.20 & 1 & 0.97 & 0.85 & 0.99 & 0.89 & 0.89 & 0.89 \\
\hline $\mathrm{CO}$ & 0.15 & 0.48 & 0.17 & 0.76 & 1 & 0.85 & 0.97 & 0.87 & 0.87 & 0.87 \\
\hline $\mathrm{BC}$ & 0.20 & 0.64 & 0.30 & 0.86 & 0.75 & 1 & 0.82 & 0.99 & 0.99 & 0.99 \\
\hline Acetonitrile & 0.11 & 0.57 & 0.23 & 0.48 & 0.52 & 0.57 & 1 & 0.86 & 0.86 & 0.86 \\
\hline$b_{\text {ap,PSAP }}(470)$ & 0.27 & 0.66 & 0.31 & 0.80 & 0.72 & 0.95 & 0.58 & 1 & 0.9999 & 0.9997 \\
\hline$b_{\mathrm{ap}, \mathrm{PSAP}}(532)$ & 0.27 & 0.63 & 0.31 & 0.80 & 0.72 & 0.95 & 0.55 & 0.99 & 1 & 0.9999 \\
\hline$b_{\text {ap,PSAP }}(660)$ & 0.28 & 0.59 & 0.29 & 0.80 & 0.70 & 0.93 & 0.51 & 0.98 & 0.99 & 1 \\
\hline
\end{tabular}
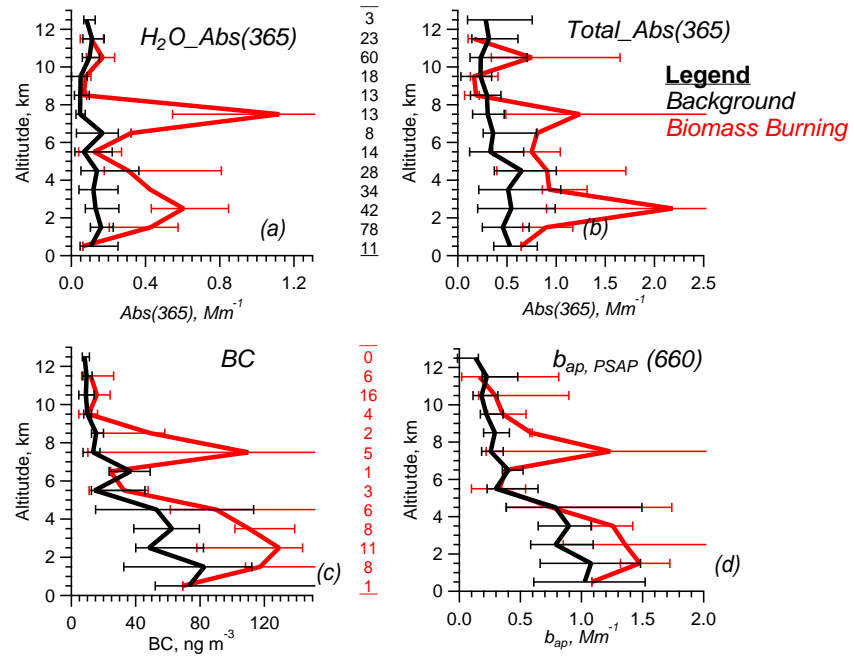

Figure 2. Vertical profiles of absorption measured in filter water extracts and the sum of water and methanol extract (total), both at $365 \mathrm{~nm}$, SP2 BC concentration, and PSAP absorption at $660 \mathrm{~nm}$. Data are binned into $1 \mathrm{~km}$ ranges and the median values are shown. Error bars indicate inter-quartile ranges. The column in the middle shows the number of data points in each altitude bin, with black for background conditions (upper) and red for biomass burning (bottom row).

\subsection{Altitude profiles of light-absorbing aerosols}

These data show that $\mathrm{BrC}$ is detected throughout the continental troposphere. Vertical profiles of $\mathrm{H}_{2} \mathrm{O}_{-} \mathrm{Abs}(365)$ and Total_Abs(365) are given in Fig. 2a and b for both the biomass-burning plumes and background conditions. The profiles were constructed by sorting the two data sets into $1 \mathrm{~km}$ bins and plotting the bin median. Error bars represent the inter-quartile ranges for each bin and demonstrate the large variability in the data, especially for the biomassburning plumes.

$\mathrm{BC}$ concentration and PSAP $b_{\text {ap }}$ at $660 \mathrm{~nm}$ are also plotted. $\mathrm{BrC}, \mathrm{BC}$, and PSAP absorption show large differences between biomass-burning events and background conditions,

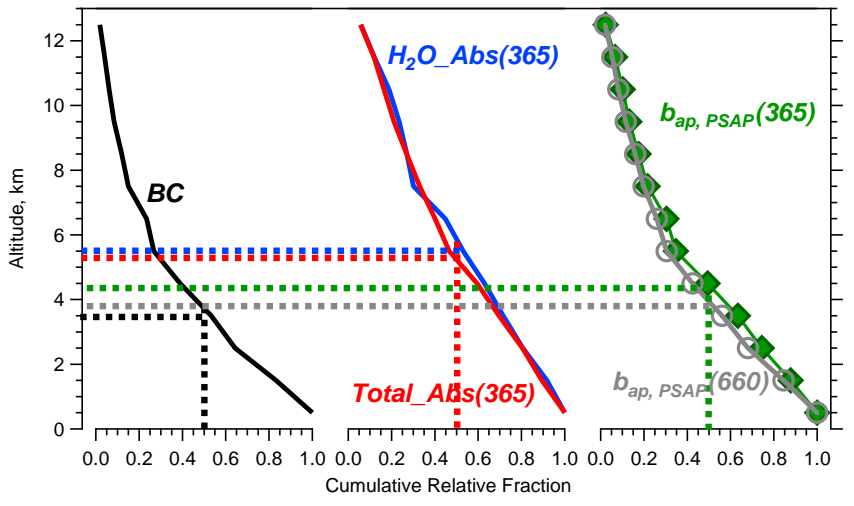

Figure 3. Vertical profile of the relative cumulative fraction (summed over all altitudes above vs. the total column), for BC (SP2), BrC at $365 \mathrm{~nm}$ based on extract solution absorption, PSAP absorption at $660 \mathrm{~nm}$, and estimated PSAP total aerosol absorption at $365 \mathrm{~nm}$, during background tropospheric conditions.

with the biomass-burning plumes dominant at a few altitudes where the aircraft encountered and pursued specific plumes. The biomass-burning altitude profiles for $\mathrm{BrC}, \mathrm{BC}$, and PSAP absorption are all somewhat similar, indicating that biomass burning contributes to all carbonaceous aerosol components that absorb light, as previously shown by the high correlations amongst these species. This is less true for background conditions where differences between the lightabsorbing components can be seen; for example, $\mathrm{BC}$ concentrations are generally more elevated closer to the surface.

To compare vertical distributions of aerosol lightabsorbing components in background air masses, the cumulative column fraction of light absorption coefficient or BC concentration is plotted in Fig. 3. At a given altitude, the cumulative fraction is the light absorption coefficient, or concentration, integrated over all altitudes above, relative to the total column. Note that the integral of the actual absorption occurring would depend on the vertical profile of actinic flux; this is independent of the relative distributions that we explore here. Half the column BC concentration occurs 
at approximately $3.5 \mathrm{~km}$ a.s.l., while for water or total (water plus methanol extract) $\mathrm{BrC}$, this occurs between 5 and $6 \mathrm{~km}$, indicating a more uniform vertical distribution and not as dominated by surface emissions compared to BC. PSAPdetermined aerosol absorption at $660 \mathrm{~nm}$ and light absorption extrapolated to $365 \mathrm{~nm}$ is also shown (the method for extrapolating is discussed below; see Eq. 7). For PSAP absorption efficiency at $365 \mathrm{~nm}$, the $50 \%$ altitude is $4.5 \mathrm{~km}$ a.s.l., which is between $\mathrm{BC}$ and $\mathrm{BrC}$, suggesting contributions to light absorption by a mixture of $\mathrm{BC}$ and $\mathrm{BrC}$ at $365 \mathrm{~nm}$, while the $50 \%$ altitude for PSAP absorption efficiency at $660 \mathrm{~nm}$ is $\sim 4 \mathrm{~km}$ a.s.l., closer to $\mathrm{BC}$, as expected, since at $660 \mathrm{~nm} \mathrm{BC}$ should dominate the total light absorption (i.e., $\mathrm{BrC}$ does not effectively absorb at high wavelengths; see next section).

The ratio of BrC (Total_Abs(365)) to the SP2-measured BC mass also increases with altitude (see Fig. S1 in the Supplement), further demonstrating the differences in vertical distributions of $\mathrm{BrC}$ and $\mathrm{BC}$ for the background troposphere. These results suggest there is in situ $\mathrm{BrC}$ production or possibly preferential loss of $\mathrm{BC}$ with increasing altitude. Higher BC at the surface may reflect greater contributions from fossil fuel combustion sources for BC. Vertical profiles of aerosols greatly affect overall radiative forcing.

\subsection{Absorption Ångström exponents for $\mathrm{BrC}$ and bulk light-absorbing aerosols}

The wavelength $(\lambda)$ dependence of light absorption is often fit with a power law:

$\operatorname{Abs}(\lambda)=K \cdot \lambda^{-\mathrm{AAE}}$,

where $\operatorname{Abs}(\lambda)$ is the light absorption at a given wavelength $(\lambda)$ for light passing through a region of light-absorbing species (e.g., the waveguide with liquid extracts, or an aerosol layer in the ambient atmosphere), and AAE is the absorption Ångström exponent (the factor $K$ is not important in this analysis). For the high spectral resolution data available with spectrophotometric measurements of absorption in the water or methanol aerosol extracts, the AAE (in this case $\mathrm{AAE}$ for $\mathrm{BrC}, \mathrm{AAE}_{\mathrm{BrC}}$ ) is determined from a linear regression fit of $\log (\operatorname{Abs}(\lambda))$ vs. $\log (\lambda)$ between 300 and $450 \mathrm{~nm}$. Examples of the solution light absorption spectra for a biomass-burning sample and typical background sample are shown in Fig. 4, along with the regression fit to determine an $\mathrm{AAE}_{\mathrm{BrC}}$. Above roughly $450 \mathrm{~nm}$, in both background and biomass-burning plumes, the $\mathrm{BrC}$ absorption levels out or increases, which may be due the chemical nature of the chromophores. This range is excluded from the $\mathrm{AAE}_{\mathrm{BrC}}$ calculation. In the following analysis, AAEs for ambient aerosols are assumed to be the same as the solution-measured $\mathrm{BrC}$ AAE (Moosmüller et al., 2011; Liu et al., 2013).

The BrC absorption Ångstöm exponents were somewhat similar for background conditions and biomass-burning samples; however, there were significant differences between water and methanol extracts. For water extracts the mean \pm SD
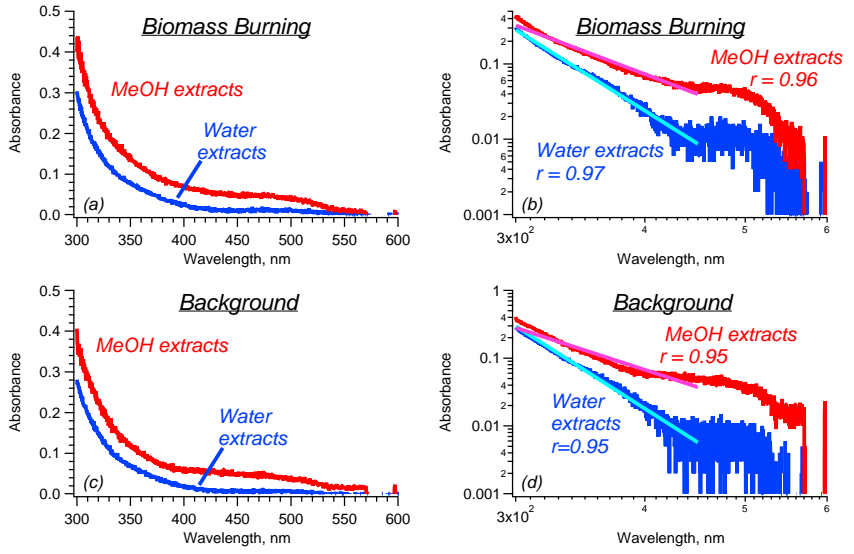

Figure 4. Example solution spectra of $\mathrm{H}_{2} \mathrm{O}$ and $\mathrm{MeOH}$ (methanol) extracts for biomass burning as well as background tropospheric conditions. Absorption Ångström exponent is calculated by a linear regression fit to $\log A b s$ vs. $\log \lambda$ in the wavelength range of $300-450 \mathrm{~nm}$, with an average $r$ value of 0.87 for water extracts, and 0.84 for methanol extracts for background data, and larger than $0.9 r$ value for biomass-burning filter extracts, for both water and methanol.

of $\mathrm{AAE}_{\mathrm{BrC}}$ was $6.82 \pm 2.63$ for background conditions and $8.95 \pm 1.73$ for biomass burning. Methanol extract $\mathrm{AAE}_{\mathrm{BrC}}$ was on average $4.54 \pm 3.07$ for background conditions and $5.04 \pm 2.61$ for biomass-burning plumes. Lower $\mathrm{AAE}_{\mathrm{BrC}}$ for methanol versus water extracts (also see Fig. 4) may be related to differences in solubility of the chromophores (Zhang et al., 2013; Chen and Bond, 2010). BrC chemical speciation by Zhang et al. (2013) found that larger molecular weight polycyclic aromatic hydrocarbons (PAHs) absorbed more toward the visible range (i.e., have a lower AAE) and have a lower water-solubility. Methanol extract lower $\mathrm{AAE}_{\mathrm{BrC}}$ could result from higher molecular weight chromophores not soluble in water.

The AAE for the overall light-absorbing ambient aerosol can also be calculated from the more limited spectral data (three wavelengths) associated with the PSAP. Here, AAE ${ }_{P S A P}$ is calculated using absorption measured at the wavelength pair, 470 and $660 \mathrm{~nm}$ by

$\operatorname{AAE}_{\text {PSAP }}=-\frac{\ln \left(b_{\text {ap,PSAP }}(660)\right)-\ln \left(b_{\text {ap,PSAP }}(470)\right)}{\ln (660)-\ln (470)}$.

AAE altitude profiles are plotted in Fig. 5. On average, there is no significant variability in the vertical profiles of background air-mass mean $\mathrm{AAE}_{\mathrm{BrC}}$, for either water or methanol extracts (Fig. 5a). There is, however, much more variability within each altitude layer. The cause of this variability could be due to aerosol chemistry, but investigating it is beyond the scope of this analysis.

$\mathrm{AAE}_{\mathrm{BrC}}$ considers only $\mathrm{BrC}$ absorbers, whereas AAEPSAP includes all absorbers (BrC and BC). Average AAE $\mathrm{ASAP}$ for the biomass-burning periods was $2.15 \pm 0.88$ (mean $\pm \mathrm{SD}$ ) 

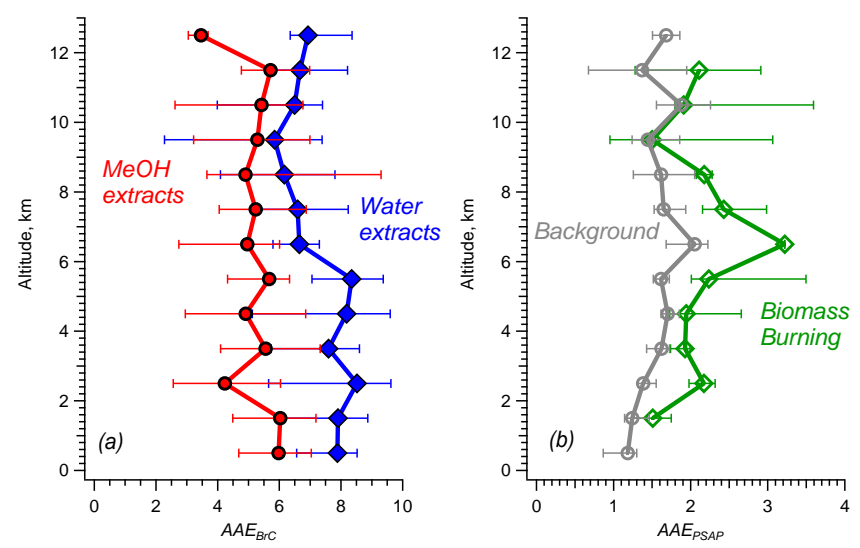

Figure 5. Vertical profiles of absorption Ångström exponent (AAE) of (a) $\mathrm{BrC}$ from solution spectra of both water extracts (blue line) and methanol extracts (red line), for background conditions, and (b) PSAP absorption measurements based on the wavelength combination $(470,660 \mathrm{~nm})$, both background and biomass-burning impacted periods. Data were binned by $1 \mathrm{~km}$ increments. Error bars indicated the inter-quartile range.

and $1.60 \pm 0.61$ for background conditions. Differences can also be seen in the vertical profiles (Fig. 5b), where for the most part, the AAEPSAP was higher in the biomass-burning plumes compared to background conditions. Qualitatively, the higher AAEPSAP for the biomass-burning air masses is consistent with significant contributions from $\mathrm{BrC}$, although light absorption enhancements due to mixing state cannot be ruled out. Another noteworthy feature of Fig. $5 b$ is that a trend in $\mathrm{AAE}_{\mathrm{PSAP}}$ may also be evident in the vertical profile for background conditions, where AAE $\mathrm{PSAP}_{\text {PA }}$ tends to increase with altitude. This is consistent with the greater fraction of $\mathrm{BrC}$ to $\mathrm{BC}$ with altitude. Note that for both biomass burning and background air masses the AAEPSAP is closer to 1 near the surface where $\mathrm{BC}$ appears to be more dominant. Overall, the independent measurements of $\mathrm{BrC}$ and aerosol AAEs are consistent and suggest that the observed AAEs greater than 1 are mostly due to $\mathrm{BrC}$ and not enhancements due to $\mathrm{BC}$ mixing state.

\subsection{Light absorption calculations: $\mathrm{BrC}, \mathrm{BC}$, and PSAP}

In the previous analysis, $\mathrm{BrC}$ solution light absorption data were presented. Now, BrC solution data are converted to optical absorption to quantify the separate contributions of $\mathrm{BrC}$ and $\mathrm{BC}$ as a function of altitude. The sum of $\mathrm{BC}$ and $\mathrm{BrC}$ absorption are then compared to the PSAP data (total $\mathrm{BrC}$ and $\mathrm{BC}$ ). The analysis could be done at any wavelength; however, $365 \mathrm{~nm}$ is chosen since it is in a wavelength range where a reliable $\mathrm{BrC}$ measurement is possible; e.g., at lower wavelengths, other non- $\mathrm{BrC}$ species begin to impact the data, such as nitrate, but sufficiently low that $\mathrm{BrC}$, if present, should have a significant optical effect (i.e., $\mathrm{BrC}$ absorption drops off rapidly with increasing wavelength, as seen above, Fig. 4).

\subsubsection{BrC light absorption}

To convert the solution absorbance to light absorption by an aerosol, knowledge of both particle morphology and how the chromophores are distributed amongst particle size is needed. In the past, studies have often assumed a small particle limit when making this conversion, where light absorption by $\mathrm{BrC}$ aerosol is taken as 0.69 to 0.75 times the light absorption of the solution (e.g., Sun et al. 2007). This likely gives a lower limit for $\mathrm{BrC}$ absorption since $\mathrm{BrC}$ is not associated with sub-nanometer size particles. Liu et al. (2013) measured the size distribution of $\mathrm{BrC}$ and showed that the chromophores were consistently found in the accumulation mode in both fresh vehicle emissions and for more aged background aerosols ( $\mathrm{BrC}$ geometric mass mean diameter was $\sim 0.5 \mu \mathrm{m}$ ). It is likely that this is more representative of the $\mathrm{BrC}$ size distribution of the background troposphere, given that the aerosols are aged. This assumption is supported by the AMS size-resolved OA data. OA was predominantly in the accumulation mode throughout the atmospheric column, excluding biomass-burning plumes. For background conditions OA geometric mass mean diameters were $0.38 \pm 0.02 \mu \mathrm{m}$ for the altitude range $0-5 \mathrm{~km}$, and $0.37 \pm 0.08 \mu \mathrm{m}$ for $5 \mathrm{~km}$ and above.

From Mie theory calculations, assuming that the $\mathrm{BrC}$ was externally mixed with other absorbers, Liu et al. (2013) found that aerosol absorption is approximately 1.8 to 2 times higher than the bulk absorption measured in the extracts. Washenfelder et al. (2015) used bulk measurements of BrC absorption at $365 \mathrm{~nm}$ to estimate the OA refractive index and used OA size distributions and Mie theory and also found a conversion factor of 2 for aerosols at a rural site. In this study, by applying Mie theory to AMS-measured size-resolved OA assuming that the $\mathrm{BrC}$ is evenly distributed amongst all $\mathrm{OA}$ (details described in Washenfelder et al., 2015), we obtain a conversion factor of $2.08 \pm 0.14$, consistent with the conversion factor of 2 obtained from Liu et al. (2013). Thus, the aerosol $\mathrm{BrC}$ absorption at $365 \mathrm{~nm}$ is estimated for the two solvent extracts simply as

$$
\begin{aligned}
& b_{\text {ap, } \mathrm{H}_{2} \mathrm{O} \_\mathrm{BrC}}(365)=2 \cdot \mathrm{H}_{2} \mathrm{O} \_\mathrm{Abs}(365), \\
& b_{\text {ap, Total_BrC }}(365)=2 \cdot\left[\mathrm{H}_{2} \mathrm{O} \_\mathrm{Abs}(365)+\mathrm{MeOH}_{-} \mathrm{Abs}(365)\right] \\
& =2 \cdot \text { Total_Abs }(365) .
\end{aligned}
$$

Considering the known uncertainty in the conversion factor of 2 (estimated to be at least $30 \%$; Liu et al., 2013) and the liquid absorption measurements, the overall uncertainty of these coefficients is estimated to be at least 30 and $45 \%$.

\subsubsection{BC and PSAP light absorption}

To estimate light absorption by the ambient aerosol at $365 \mathrm{~nm}$, PSAP measurements at higher wavelengths are ex- 
trapolated to $365 \mathrm{~nm}$ using a calculated AAEPSAP. Particle absorption at a certain wavelength, $b_{\mathrm{ap}, \operatorname{PSAP}}(\lambda)$, is calculated from the AAEPSAP from Eq. (4) and the light absorption measured at $660 \mathrm{~nm}$ :

$b_{\text {ap, } \operatorname{PSAP}}(\lambda)=b_{\text {ap,PSAP }}(660) \cdot\left(\frac{\lambda}{660}\right)^{-\operatorname{AAE}_{\mathrm{PSAP}}}$.

It is noted that AAEPSAP, given in Eq. (4), could have been determined from different wavelength combinations (i.e., 470-532, 532-660 nm). For this data set, the other wavelength pairs led to a predicted $b_{\text {ap,PSAP }}(365)$ systematically different by roughly $20 \%$ of that predicted by Eqs. (4) and (7). The wavelength pair of 470 and 532 results in a $b_{\text {ap,PSAP }}(365)$ that was $\sim 20 \%$ higher (regression slope $=1.19, r^{2}=0.98$, intercept $=-0.02$ for $b_{\text {ap,PSAP }}(365)$ predicted from 470 to 532 vs. $b_{\text {ap,PSAP }}(365)$ predicted from 470 to 660 wavelength pair), whereas the other combination produces a systematically $20 \%$ lower $b_{\text {ap,PSAP }}(365)$ (regression slope $=0.80, r^{2}=0.94$, intercept $=0.04$ for $b_{\text {ap,PSAP }}(365)$ from 532 to 660 vs. $b_{\text {ap,PSAP }}(365)$ predicted from 470 to 660 wavelength pair). Thus, the $470-660$ pair gives the middle value between what is predicted by other possible combinations (see Liu et al., 2014 for how the choice of wavelength pair influences the vertical distribution of AAE ${ }_{\text {PSAP). }}$.

Since data on light absorption by BC are not available, it was estimated. A number of possible methods are available. In the first case, $\mathrm{BC}$ absorption at a certain wavelength $\left(b_{\mathrm{ap}, \mathrm{BC} 1}(\lambda)\right)$ is calculated from light absorption coefficients recorded at high wavelengths, where contributions from $\mathrm{BrC}$ should be minimal, and extrapolated to lower wavelengths using an assumed $\mathrm{BC} \mathrm{AAE}\left(\mathrm{AAE}_{\mathrm{BC}}\right)$,

$b_{\mathrm{ap}, \mathrm{BC} 1}(\lambda)=b_{\mathrm{ap}, \operatorname{PSAP}}(660) \cdot\left(\frac{\lambda}{660}\right)^{-\mathrm{AAE}_{\mathrm{BC}}}$.

Aged BC aerosol is likely to be internally mixed with other aerosol components, which, based on simplified models, such as spherical clear shells over absorbing BC cores (Bond et al., 2006), and limited laboratory data (Schnaiter et al., 2005; Slowik et al., 2007), could lead to a significantly different $\mathrm{AAE}_{\mathrm{BC}}$, for example, ranging from $\sim 0.6$ to 1.6 (Kirchstetter and Thatcher, 2012; Feng et al., 2013; Lack and Cappa, 2010; Liu et al., 2015). More random mixtures, or mixtures containing absorbing material, such as $\mathrm{BrC}$, can significantly alter this enhancement (Lack and Cappa, 2010). Recent ambient data do not show significant enhancement of aerosol light absorption at lower wavelengths, which would be indicated by deviation of an $\mathrm{AAE}_{\mathrm{BC}}$ from 1 (Cappa et al., 2012). In the following analysis, an $A A E_{B C}$ of 1 is used as the default case.

Instruments that measure light absorption based on particles deposited on a filter, such as the PSAP, can also be significantly biased high due to artifacts (Lack et al., 2008). To avoid this, an alternative approach to calculate $\mathrm{BC}$ absorption is to estimate the light absorption coefficient at high

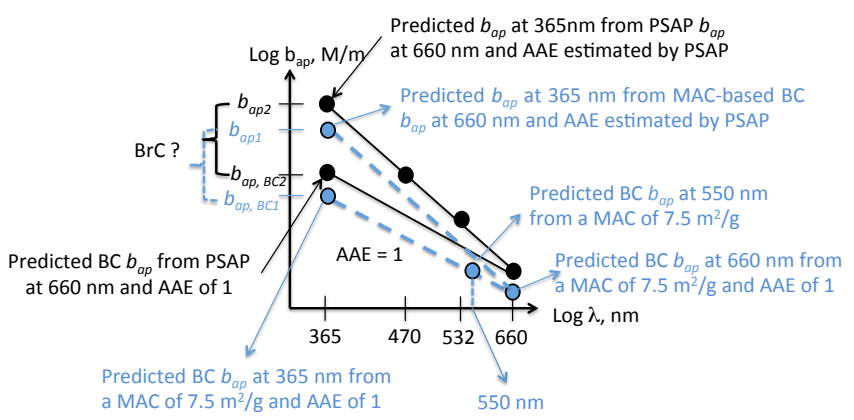

Figure 6. Schematic of how ambient aerosol and BC absorption was extrapolated to lower wavelengths. Square data points represent PSAP measurement, which are used to estimate the ambient aerosol AAE (AAEPSAP; not shown but is the slope of upper lines), and used to predict ambient aerosol absorption at $365 \mathrm{~nm}$ ( $\left.b_{\text {ap,PSAP }}\right)$. Light absorption by black carbon $\left(b_{\mathrm{ap}, \mathrm{BC}}\right)$ is estimated assuming an $\mathrm{AAE}_{\mathrm{BC}}$ of 1 and extrapolating from the PSAP measurement at $660 \mathrm{~nm}$, a size where $\mathrm{BrC}$ absorption is minimal, or alternatively assuming a BC MAC of $7.5 \mathrm{~m}^{2} \mathrm{~g}^{-1}$ at $550 \mathrm{~nm}$ and extrapolating to $365 \mathrm{~nm}$ with an $\mathrm{AAE}_{\mathrm{BC}}$ of 1 .

wavelengths, where $\mathrm{BrC}$ does not absorb light, using the $\mathrm{BC}$ mass concentration and an assumed characteristic $\mathrm{BC}$ mass absorption cross section (MAC) at a given wavelength. BC absorption at other wavelengths can be determined using the $\mathrm{AAE}_{\mathrm{BC}}$. Bond and Bergstrom (2006) suggested a $\mathrm{MAC}_{\mathrm{BC}}=$ $7.5 \pm 1.2 \mathrm{~m}^{2} \mathrm{~g}^{-1}$ at $550 \mathrm{~nm}$ for pure uncoated (i.e., fresh) $\mathrm{BC}$. Here, we use this as a possible lower bound for BC light absorption and refer to this second method of calculating the BC absorption with a subscript 2,

$b_{\mathrm{ap}, \mathrm{BC} 2}(\lambda)=\mathrm{MAC}_{\mathrm{BC}} \cdot \mathrm{BC} \cdot\left(\frac{\lambda}{550}\right)^{-\mathrm{AAE}_{\mathrm{BC}}}$.

For consistency, this prediction of $\mathrm{BC}$ absorption is compared to the ambient aerosol absorption $\left(b_{\mathrm{ap} 2}\right)$, which is estimated by extrapolating from this MAC-determined light absorption coefficient $\left(b_{\mathrm{ap}, \mathrm{BC} 2}\right)$ using the PSAP AAE,

$b_{\mathrm{ap} 2}(\lambda)=b_{\mathrm{ap}, \mathrm{BC} 2}(\lambda) \cdot\left(\frac{660}{\lambda}\right)^{-\mathrm{AAE}_{\mathrm{BC}}} \cdot\left(\frac{\lambda}{660}\right)^{-\mathrm{AAE}_{\mathrm{PSAP}}}$.

A schematic showing the various optical calculations is given in Fig. 6.

In this data set, the second approach leads to a lower prediction of $\mathrm{BC}$ absorption compared to the first method (i.e., $b_{\mathrm{ap}, \mathrm{BC} 2}<b_{\mathrm{ap}, \mathrm{BC} 1}$, see Fig. 6 ) due to differences between the assumed $\mathrm{MAC}_{\mathrm{BC}}$ and the PSAP-measured MAC. For this data set, the non-biomass-burning study-average MAC at $660 \mathrm{~nm}$ is $10.9 \mathrm{~m}^{2} \mathrm{~g}^{-1}$ (see Fig. S2). This is roughly $75 \%$ higher than the assumed pure $\mathrm{BC} M \mathrm{MC}_{\mathrm{BC}}$, where $\mathrm{MAC}_{\mathrm{BC}}$ at $550 \mathrm{~nm}$ was converted to a $\mathrm{MAC}_{\mathrm{BC}}$ at $660 \mathrm{~nm}$, by assuming an $\mathrm{AAE}_{\mathrm{BC}}$ of 1 , resulting in $\mathrm{MAC}_{\mathrm{BC}}$ at $660 \mathrm{~nm}=6.3 \mathrm{~m}^{2} \mathrm{~g}^{-1}$. Observed MACs are often found to vary substantially (Chan et al., 2011), and some of this variability is thought to be due 


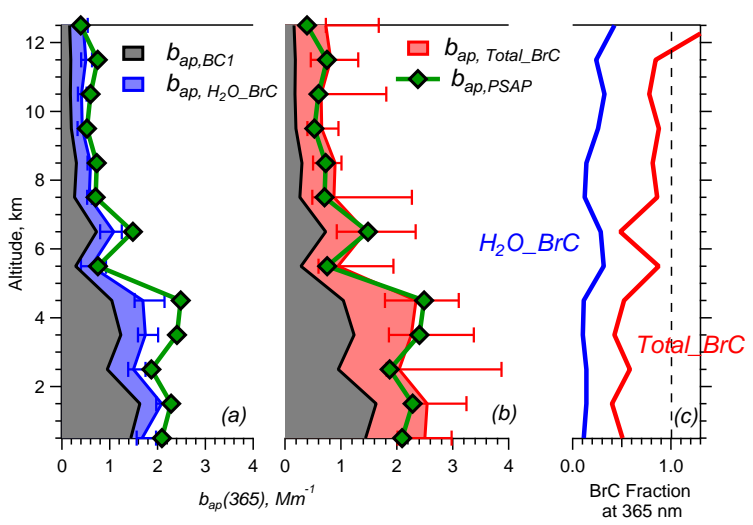

Figure 7. Vertical profiles of estimated aerosol optical absorption at $365 \mathrm{~nm}$ by $\mathrm{BrC}, \mathrm{BC}$, determined by an extrapolation from PSAP absorption at $660 \mathrm{~nm}$ ( $b_{\mathrm{ap}, \mathrm{BC} 1}$ shown in the schematic), and the sum of $\mathrm{BrC}$ and $\mathrm{BC}$ compared to total light absorbing determined from the PSAP data. (a) shows water-soluble BrC (blue shaded), (b) the total $\mathrm{BrC}$ (red shaded), and (c) relative contribution of $\mathrm{BrC}$ to total aerosol absorption. In all plots, median values are shown and error bars indicate the inter-quartile range of estimated $\mathrm{BrC}$ absorption for each $1 \mathrm{~km}$ altitude bin. (Measurement uncertainties of the various absorption coefficients are estimated to be between \pm 28 and $\pm 45 \%$ ). Only background tropospheric data are plotted.

to internal mixing of BC (see Bond et al., 2013, for a review). In summarizing observations of ambient aerosol BC MACs, Bond et al. (2013) suggested that a $\mathrm{MAC}_{\mathrm{BC}} 50 \%$ greater than that of pure $\mathrm{BC}$ is reasonable (Bond et al., 2013), which is not significantly different from what we observed. This suggests that the PSAP data for background conditions may not be highly skewed by artifacts.

The schematic in Fig. 6 suggests that light absorption by the ambient aerosol at $365 \mathrm{~nm}$ (e.g., $\left.b_{\text {ap,PSAP }}(365)\right)$ is higher than that predicted at the same wavelength for BC (e.g., $\left.b_{\mathrm{ap}, \mathrm{BC} 1}(365)\right)$. This is often interpreted to be due to additional absorption by $\mathrm{BrC}$ (Kirchstetter et al., 2004; Sandradewi et al., 2008; Chen and Bond, 2010; Sun et al., 2007; Clarke et al., 2007) and is due to the ambient AAE (AAEPSAP) being greater than $\mathrm{AAE}_{\mathrm{BC}}$ (i.e., 1). However, as noted above, due to uncertainties associated with these various calculations, such as possible variability in $\mathrm{AAE}_{\mathrm{BC}}$, definitively attributing the difference to be due to $\mathrm{BrC}$ is highly uncertain. However, in this case we have a direct measurement of $\mathrm{BrC}$ and an optical closure analysis can be performed to assess if $\mathrm{BrC}$ is a reasonable explanation for the difference.

\subsection{Optical importance of $\mathrm{BrC}$ relative to $\mathrm{BC}$ and a closure assessment by comparison to PSAP absorption}

In the following we focus on $\mathrm{BC}$ absorption based on the PSAP measurements and an assumed $\mathrm{AAE}_{\mathrm{BC}}$ of 1 (i.e., $\left.b_{\mathrm{ap}, \mathrm{BC} 1}\right)$. Results using the other measure of $\mathrm{BC}$ absorption $\left(b_{\mathrm{ap}, \mathrm{BC} 2}\right)$ are discussed, but not plotted.

\subsubsection{Background conditions}

Vertical profiles of altitude-binned median data of the light absorption coefficients at $365 \mathrm{~nm}$ for $\mathrm{BC}\left(b_{\mathrm{ap}, \mathrm{BC} 1}\right)$, plus either water-soluble $\mathrm{BrC}\left(b_{\mathrm{ap}, \mathrm{H}_{2} \mathrm{O} \_\mathrm{BrC}}\right)($ Fig. $7 \mathrm{a})$, or total $\mathrm{BrC}$ $\left(b_{\text {ap, Total_BrC }}\right)$, are shown in Fig. 7 , along with the PSAP data extrapolated to $365 \mathrm{~nm}\left(b_{\text {ap,PSAP }}\right)$ representing the ambient light absorption coefficient. Figure 7 shows that absorption drops off with increasing altitude. It is also evident that the absorption of just black carbon $\left(b_{\mathrm{ap}, \mathrm{BC} 1}\right)$ is always significantly less than the overall ambient aerosol absorption determined from the PSAP, at $365 \mathrm{~nm}\left(b_{\text {ap,PSAP }}\right)$. Water-soluble $\mathrm{BrC}$ absorption, $b_{\mathrm{ap}, \mathrm{H}_{2} \mathrm{O} \_\mathrm{BrC}}(365)$, is small relative to $\mathrm{BC}$ and the sum of the two is always lower than the observed absorption ( $\left.b_{\text {ap,PSAP }}\right)$, which is reasonable as the water-soluble fraction is only a portion of the light-absorbing organics. Total BrC absorption, $b_{\text {ap,Total_BrC }}(365)$, on the other hand, is more comparable to $\mathrm{BC}$ absorption over most of the altitude range, and when the two are summed, the $\mathrm{BC}+\mathrm{BrC}$ tends to agree with the observed absorption. (Note, measurement uncertainties are roughly 28 to $45 \%$ for the various light absorption coefficients.)

A more quantitative assessment of closure for background conditions can be seen in a scatter plot with orthogonal distance regression of the sum of the estimated $\mathrm{BC}$ and $\mathrm{BrC}$ versus PSAP absorption (Fig. 8). From Fig. 8a, on average for background tropospheric conditions, at $365 \mathrm{~nm} \mathrm{BC}$ accounts for roughly $74 \%$ of the ambient absorption. When the watersoluble $\mathrm{BrC}$ is added, a slope of 0.90 (Fig. 8b) indicates that the $\mathrm{BC}$ plus water-soluble $\mathrm{BrC}$ improves the closure, but still slightly underpredicts the light absorption coefficient. When the total $\mathrm{BrC}$ is used (water + methanol extractions) the sum of $\mathrm{BC}$ and $\mathrm{BrC}$ results in a slope near 1 (0.97), but with a positive intercept at $0.56 \mathrm{M} \mathrm{m}^{-1}$. If the regression is forced through zero, the slope is 1.16 . If the low particle limit is used in the conversion of solvent extracts absorption to ambient particle absorption (instead of the factor of 2; Liu et al., 2013), the slope would be 0.76 for $\mathrm{BC}+$ water-soluble $\mathrm{BrC}$, and 0.85 for $\mathrm{BC}+$ total $\mathrm{BrC}$ vs. ambient. These comparisons have assumed an $\mathrm{AAE}_{\mathrm{BC}}$ of 1 , but a range of values are possible (i.e., Gyawali et al., 2009). In this case, an $\mathrm{AAE}_{\mathrm{BC}}$ value of 0.82 would result in a regression slope of 1 between the sum of $\mathrm{BC}$ and $\mathrm{BrC}$ absorption versus $b_{\mathrm{ap}, \mathrm{PSAP}}$ at $365 \mathrm{~nm}$, for a solution conversion factor of 2 . One cannot definitively attribute all enhanced light absorption at low wavelengths to $\mathrm{BrC}$; some combination of enhancement due to $\mathrm{BC}$ mixing and $\mathrm{BrC}$ is possible. In this data set, however, an enhancement in light absorption at low wavelengths is most consistent with just $\mathrm{BrC}$.

Light absorption closure was carried out based on the assumption that $\mathrm{BrC}$ is externally mixed with $\mathrm{BC}$. Mie theory calculations were performed using the internally mixed assumption, with core-shell sizes estimated from $\mathrm{OA}$ : $\mathrm{BC}$ ratios obtained from AMS and SP2 measurements. BC core refractive index was set at 1.950-0.79i (Bond et al., 2013). OA 

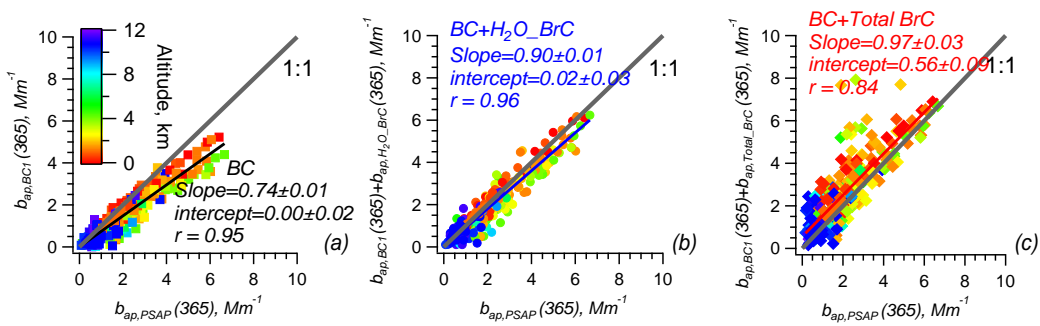

Figure 8. Closure analysis of $b_{\mathrm{ap}}$ at $365 \mathrm{~nm}$ for background tropospheric conditions. Scatter plots of estimated (a) BC absorption, (b) sum of $\mathrm{BC}$ absorption and water-soluble BrC absorption, and (c) sum of $\mathrm{BC}$ absorption and total BrC absorption, compared with total aerosol absorption estimated by PSAP. Markers are color-coded by altitude. Orthogonal distance regression (ODR) fit results are shown. The $1: 1$ line is also included. (Measurement uncertainties of the various absorption coefficients are estimated to be between \pm 28 and $\pm 45 \%$.)

shell refractive index was set at $1.55-0.00156 i$ at $365 \mathrm{~nm}$, in which 1.55 was from literature (e.g., Bond and Bergstrom, 2006; McMeeking et al., 2005), and the imaginary part was determined from bulk measurements of $\mathrm{BrC}$ absorption at $365 \mathrm{~nm}$ and $\mathrm{OA}$ mass concentration measured by AMS using the equation below, following the method in Liu et al. (2013):

$k=\frac{\rho \cdot \lambda \cdot \operatorname{MAC}(\lambda)}{4 \pi}=\frac{\rho \cdot \lambda \cdot \operatorname{Total} \_\operatorname{Abs}(\lambda)}{4 \pi \cdot \mathrm{OM}}$.

Based on these assumptions, the light absorption estimated for the core-shell is 3.3 times that of only the $\mathrm{BC}$ core, and will be 2.4 times of the aerosol light absorption measured by the PSAP. In contrast, assuming $\mathrm{BrC}$ and $\mathrm{BC}$ are externally mixed (no core-shell enhancements), estimated light absorption at $365 \mathrm{~nm}$ from the PSAP was within roughly $25 \%$ of that assuming external mixtures (see Figs. 8 and 9). In this case, we believe the external mixing assumption provides a more reasonable closure on light absorption.

Finally, in the previous sections we showed the prevalence of $\mathrm{BrC}$ increases relative to $\mathrm{BC}$ with increasing altitude, based on solution data. Now that the closure analysis provides some support for the $\mathrm{BrC}$ absorption coefficients at $365 \mathrm{~nm}$, the fractional contribution of $\mathrm{BrC}$ absorption (both water and total $\mathrm{BrC}$ ) relative to ambient absorption can be assessed as a function of altitude. Figure $7 \mathrm{c}$ shows that the fraction of $\mathrm{BrC}$ substantially increases with increasing altitude, with absorption due to total $\mathrm{BrC}$ (at $365 \mathrm{~nm}$ ) accounting for $>80 \%$ of total absorption above $\sim 7.5 \mathrm{~km}$, a region where ambient absorption coefficients are low.

\subsubsection{Biomass-burning events}

Applying a vertical distribution analysis is not possible for biomass-burning plumes, since there were limited data points for some of the altitudes, but closure analysis based on the combined data is shown in Fig. 9. The conversion factor from solution $\mathrm{BrC}$ to ambient aerosol absorption has not been studied for biomass-burning events (Liu et al., 2013 did not include a size-resolved measure of biomass-burning $\mathrm{BrC}$ ), leading to some uncertainty in this closure analysis. As be- fore a multiplication factor of 2 is used as the base case, recognizing there is uncertainty in this assumption.

Biomass burning is known to be a strong source for $\mathrm{BrC}$, and Fig. 9a shows that on average, at $365 \mathrm{~nm} \mathrm{BC}$ only accounted for roughly $57 \%$ of the light absorption, substantially lower than that for background conditions. For BC plus water-soluble $\mathrm{BrC}$ the slope is $77 \%$ and, for $\mathrm{BC}$ plus total $\mathrm{BrC}$ the slope is $122 \%$, in this case overpredicting the observed values. An $\mathrm{AAE}_{\mathrm{BC}}$ value of 0.82 , which resulted in a slope of 1 for background conditions, results in a smaller (9\%) overestimation for the biomass-burning plumes. More studies of individual biomass-burning plumes would provide greater insight into possible roles of both $\mathrm{BC}$ mixing and $\mathrm{BrC}$ in light absorption enhancements.

\subsubsection{Use of the MAC in closure calculations for background conditions}

A similar analysis, but where $\mathrm{BC}$ and ambient light absorption are based on an assumed BC MAC, SP2-measured BC concentrations, and PSAP AAE (i.e., see Fig. $6 ; b_{\mathrm{ap}, \mathrm{BC} 2}$ and

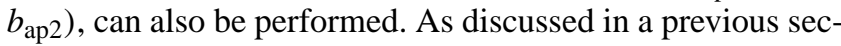
tion, this approach leads to a lower prediction of $\mathrm{BC}$ absorption compared to the first method (i.e., $b_{\mathrm{ap}, \mathrm{BC} 2}<b_{\mathrm{ap}, \mathrm{BC} 1}$ ), and therefore a lower $b_{\mathrm{ap} 2}$ than $b_{\mathrm{ap}, \mathrm{PSAP}}$ at $365 \mathrm{~nm}$ (Fig. 6). In this case the closure analysis for $\mathrm{BC}$ versus ambient light absorption $\left(b_{\mathrm{ap} 2}\right)$ results in a slope of 0.73 , whereas for $\mathrm{BC}+$ water-soluble $\mathrm{BrC}$ the slope is 0.97 , and for total $\mathrm{BrC}$ the slope is 1.40. Thus, unlike when the PSAP absorption coefficients at $660 \mathrm{~nm}$ are used directly, the sum of BC and $\mathrm{BrC}$ light absorption generally exceeds the ambient total $\mathrm{ab}$ sorption. This happens because using a MAC of pure BC results in substantially lower absorption coefficients, making the proportion of $\mathrm{BrC}$ higher. It appears that the use of the $\operatorname{MAC}_{\mathrm{BC}}\left(7.5\right.$ at $550 \mathrm{~nm}$ or $6.3 \mathrm{~m}^{2} \mathrm{~g}^{-1}$ at $\left.660 \mathrm{~nm}\right)$ in this case does not produce as reasonable a result as absorption coefficients based on the PSAP data (observed study MAC of $10.9 \mathrm{~m}^{2} \mathrm{~g}^{-1}$ at $660 \mathrm{~nm}$ ) and so this method is not considered in the radiative forcing calculations that follow. 

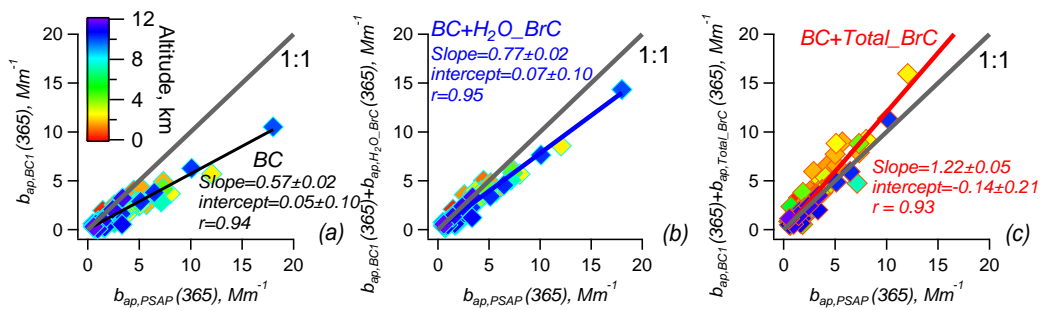

Figure 9. Closure analysis of $b_{\text {ap }}$ at $365 \mathrm{~nm}$ for biomass-burning plumes via scatter plots of estimated (a) BC absorption, (b) sum of BC absorption and water-soluble $\mathrm{BrC}$ absorption, and (c) sum of $\mathrm{BC}$ absorption and total $\mathrm{BrC}$ absorption compared with total aerosol absorption based on PSAP data. Markers were color-coded by altitude. Orthogonal distance regression (ODR) fit results are shown. The $1: 1$ line is also included. (Measurement uncertainties of the various absorption coefficients are estimated to be between \pm 28 and $\pm 45 \%$.)

\subsection{Radiative forcing}

The Santa Barbara DISORT Atmospheric Radiative Transfer (SBDART) model was used to assess the role of $\mathrm{BrC}$ in direct radiative forcing for background conditions in the continental troposphere. Vertically resolved optical properties were used, including light absorption coefficients for $\mathrm{BC}, \mathrm{BrC}$, and total absorption based on the PSAP, along with measurements of the light scattering coefficients from the multi-wavelength nephelometer. Absorption and scattering coefficients were calculated for 10 wavelengths, over the $300-700 \mathrm{~nm}$ range, and average values were determined for each $1 \mathrm{~km}$ altitude bin. $\mathrm{BC}$ absorption was determined using Eq. (8) and $\mathrm{AAE}_{\mathrm{BC}}=1, \mathrm{BrC}$ was determined based on the complete measured spectra of total (water + methanol) solution data, and overall ambient aerosol light absorption was based on Eq. (7) and inferred AAEPSAP. Scattering coefficients were determined from Eq. (2). The scattering is based on measurements and independent of the light absorption used (i.e., just $\mathrm{BC}$ or $\mathrm{BC}$ plus $\mathrm{BrC}$ ). The wavelengthdependent single scattering albedo (SSA) was then calculated as input to the SBDART model. Aerosol optical depth was also calculated using absorption and scattering data. The SBDART model interpolated from these data over the wavelength range of $250-4000 \mathrm{~nm}$. A third input needed for SBDART is the asymmetry parameter $(g)$, of which a uniform value of 0.65 (Carrico et al., 2003) was used across all wavelengths. An atmospheric profile for a standard mid-latitude summer was assumed and tested with albedo resulting from surface types of both sand and vegetation. The model was run with solar zenith angle (SZA) ranging from 0 to $85^{\circ}$, at $5^{\circ}$ increments. Daily average forcing is the integrated instantaneous radiative forcing averaged over a $24 \mathrm{~h}$ period.

To assess the influence of $\mathrm{BrC}$ relative to $\mathrm{BC}$, forcing was calculated based on the estimates of $\mathrm{BC}$ optical properties $\left(\mathrm{AAE}_{\mathrm{BC}}=1\right)$, then compared to forcing for $\mathrm{BC}+\mathrm{BrC}$. Four groups of wavelength-dependent inputs were generated for each altitude bin: no aerosol (gases only), scattering aerosols only, $\mathrm{BC}$ as the only absorbing aerosol, and $\mathrm{BC}+\mathrm{BrC}$ as absorbing aerosols. Only background data were used (i.e., biomass-burning plumes were excluded), to better represent typical continental atmospheric conditions. At a SZA of $40^{\circ}$, considering all aerosol direct optical effects, but delineating absorption by $\mathrm{BC}$ and $\mathrm{BrC}$, the instantaneous forcings at TOA were -19.33 and $-24.84 \mathrm{~W} \mathrm{~m}^{-2}$ for $\mathrm{BC}+\mathrm{BrC}$ and $\mathrm{BC}$, respectively, with vegetation as surface type, and -23.35 and $-28.57 \mathrm{~W} \mathrm{~m}^{-2}$ for a surface of sand. Integrated over a $24 \mathrm{~h}$ period, diurnally averaged forcings at TOA were -14.79 and $-11.82 \mathrm{~W} \mathrm{~m}^{-2}$ for $\mathrm{BC}$ and $\mathrm{BC}+\mathrm{BrC}$, vegetation surface type, and -16.94 and $-14.11 \mathrm{~W} \mathrm{~m}^{-2}$, respectively, for a surface type of sand. The overall negative TOA forcing is due to cooling by aerosol scattering; however, $\mathrm{BrC}$ absorption appreciably changes the TOA forcing relative to $\mathrm{BC}$ only, resulting in roughly $20 \%$ less cooling compared to only BC. The forcings at the surface are discussed in Liu et al. (2014).

Alternatively, we could use the PSAP data to estimate total light absorption by aerosols instead of $\mathrm{BC}+\mathrm{BrC}$, in which case we get light absorbers other than $\mathrm{BC}$ (eg, $\mathrm{BrC}$, dust) contributing $\sim 17 \%$, similar to the values reported above. Other combinations of the analyses are possible, but all give similar results. Therefore, for the aerosol loadings recorded in this study, we find that $\mathrm{BrC}$ increased the shortwave solar absorption in the atmosphere by approximately $20 \%$, demonstrating the importance of $\mathrm{BrC}$ as a climate forcing agent.

Most measurements of $\mathrm{BrC}$ and other aerosol optical properties are made at the surface. To allow for estimates of TOA forcing due to contributions of aerosol $\mathrm{BrC}$ throughout the column, the average distributions of SSA and optical depth observed under background conditions are used to generate a chart relating aerosol radiative forcing efficiencies $\left(\mathrm{RF}_{\text {eff }}\right)$ as a function of the aerosol absorption coefficient of $\mathrm{BrC}$ relative to $\mathrm{BC}$ at $365 \mathrm{~nm}$ and SSA measured at the surface. The $\mathrm{RF}_{\text {eff }}$ is defined as the TOA aerosol radiative forcing divided by AOD at $500 \mathrm{~nm}$. Figure 10 was generated through multiple runs $(N=4320)$ of SBDART and shows that $\mathrm{RF}_{\text {eff }}$ values of $\mathrm{BrC}$ increase with decreasing SSA and increasing $\mathrm{BrC}: \mathrm{BC}$ ratio, as both factors result in higher $\mathrm{BrC}$ at a given AOD. The circle in the Fig. 10 represents the average background conditions during this campaign, with a value of $16.71 \mathrm{~W} \mathrm{~m}^{-2}$ per unit optical depth at $500 \mathrm{~nm}$, with a surface of vegetation. In comparison, the forcing efficiency is $-88.64 \mathrm{~W} \mathrm{~m}^{-2}$ per unit optical depth at $500 \mathrm{~nm}$ 


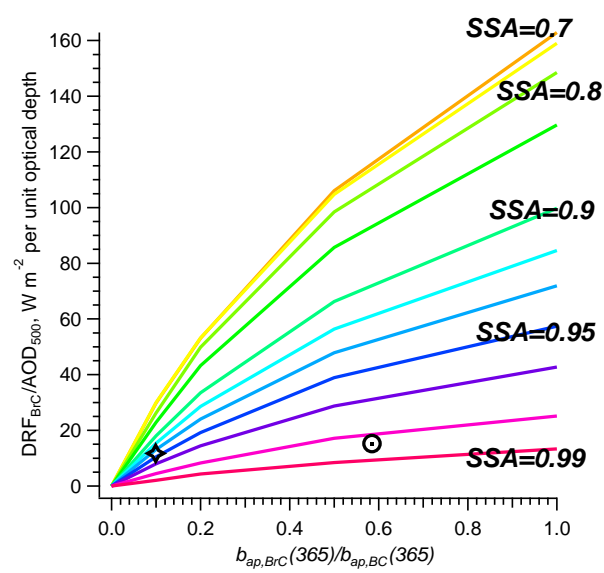

Figure 10. $\mathrm{BrC}$ radiative forcing efficiencies, defined as the $\mathrm{BrC}$ TOA direct radiative forcing divided by AOD at $500 \mathrm{~nm}$, as a function of $\mathrm{BrC}$ to $\mathrm{BC}$ absorption ratio and SSA measured at surface at $365 \mathrm{~nm}$. The circle corresponds to average background conditions determined from the DC3 campaign. The star represents a surface measurement from southeast USA, where altitude-resolved data were not available.

for $\mathrm{BC}+$ scattering, which is in agreement with previous research (e.g., Bush and Valero 2003).

If the vertical profiles applied in SBDART represents typical background tropospheric conditions in the continental USA, application of Fig. 10 is not limited to this campaign. Further airborne studies similar to this one are needed to assess this assumption. As noted, the SSA and BrC/BC absorption ratios plotted in the figure are surface values at $365 \mathrm{~nm}$, while column AOD could be easily retrieved from remote sensing techniques; for example, AOD at $500 \mathrm{~nm}$ is available from AERONET. Therefore, the figure can serve as a lookup chart to estimate radiative forcing contributions by $\mathrm{BrC}$, when altitude-resolved parameters are not available. For example, a data point for surface measurements at a rural site in the southeastern USA (Washenfelder et al., 2015) is also shown in Fig. 10. In addition, large-scale models require substantial number of computations, the patterns shown in this figure could be considered as a simplified module and incorporated into models with minimal computational costs.

\section{Summary}

Direct measurements of $\mathrm{BrC}$ were made on solvent extracts from filters collected at altitudes ranging from approximately 1 to $12 \mathrm{~km}$ over the central USA during summer. The data were segregated into periods of sampling in biomass-burning plumes and more typical background tropospheric conditions. The filters were extracted sequentially: first in water, then in methanol, and the sum of the water plus methanol extract $\mathrm{BrC}$ assumed to represent the total $\mathrm{BrC}$.

During biomass-burning periods, both water- and methanol-soluble $\mathrm{BrC}$ were highly correlated with other known emissions from biomass-burning plumes, including $\mathrm{CO}$, acetonitrile, and $\mathrm{BC}$. Under background conditions, the water-soluble fraction of $\mathrm{BrC}$ was somewhat correlated with smoke tracers, whereas the methanol-soluble $\mathrm{BrC}$ was not well correlated with any specific tracers, but most correlated with WSOC, possibly due to the $\mathrm{BrC}$ evolving to a more water-insoluble state as it aged. $\mathrm{BrC}$ was 4 to 5 times higher in biomass-burning plumes relative to the background conditions and more water-soluble (45\% of the total, at $365 \mathrm{~nm}$, in the biomass-burning plumes versus $30 \%$ in background air).

$\mathrm{BrC}$ was found throughout the tropospheric column. For background conditions, $\mathrm{BrC}$ was more evenly distributed throughout the column than $\mathrm{BC}$, resulting in an increasing proportion of $\mathrm{BrC}$ relative to $\mathrm{BC}$, with increasing altitude. This was consistent with an observed increasing AAE from the three-wavelength PSAP data.

Estimates of $\mathrm{BC}$ and $\mathrm{BrC}$ absorption coefficients at $365 \mathrm{~nm}$ were compared to observed PSAP absorption. For background air masses, a closure between $\mathrm{BC}+\mathrm{BrC}$ versus ambient absorption coefficients derived from the PSAP resulted in a slope within $3 \%$ of one. For biomass-burning plumes the closure was within $22 \%$. Reasonable closure suggests that PSAP AAEs greater than 1 were mainly due to the presence of $\mathrm{BrC}$ and not due to enhancements from $\mathrm{BC}$ internal mixing with other compounds, although the data do not definitely prove this.

To estimate the $\mathrm{BrC}$ contribution to climate forcing, the vertically resolved data were applied to a radiative transfer model (SBDART). The overall negative TOA forcing by aerosol scattering was reduced by approximately $20 \%$ due to $\mathrm{BrC}$ absorption. Thus, for the aerosol loadings recorded during this study under background conditions, $\mathrm{BrC}$ increased the shortwave solar absorption in the atmosphere by roughly $20 \%$ over what would occur if it were not present. These results demonstrate that $\mathrm{BrC}$ is an important climate forcing agent and should be considered in global climate models.

Because there are differences between $\mathrm{BC}$ and $\mathrm{BrC}$ sources and vertical distributions, the latter has an impact on the radiative forcing (Samset and Myhre, 2011); BrC cannot be accurately represented by a simple scaling of BC. Furthermore, this study and others (Lee et al., 2014; Zhong and Jang, 2014) show that $\mathrm{BrC}$ is dynamic with significant changes possibly occurring with photochemical aging, making predicting $\mathrm{BrC}$ levels and optical effects of $\mathrm{BrC}$ absorption complex. Instead a look-up chart was developed based on the average vertical profile for atmosphere background conditions in this study. The chart provides estimates of $\mathrm{BrC}$ radiative forcing based on three surface-measured aerosol parameters. The look-up chart is an important first attempt at developing a tool to assess the role of $\mathrm{BrC}$ radiative forcing and aid in including $\mathrm{BrC}$ in global models. Measurements of well-aged $\mathrm{BrC}$ vertical profiles similar to those of this study are needed in other locations to improve the predictability of this type of model. 


\section{The Supplement related to this article is available online at doi:10.5194/acp-15-7841-2015-supplement.}

Acknowledgements. This project was funded by GIT NASA contracts NNX12AB83G and NNX08AH80G and UNH NASA contract NNX12AB80G. Acetonitrile measurements onboard the DC-8 were supported by BMVIT/FFG-ALR and the NASA Postdoctoral Program. P. Campuzano-Jost, D. A. Day, and J. L. Jimenez were supported by NASA NNX12AC03G. The authors thank the DC3 personnel for logistical support.

Edited by: N. M. Donahue

\section{References}

Andreae, M. O. and Gelencsér, A.: Black carbon or brown carbon? The nature of light-absorbing carbonaceous aerosols, Atmos. Chem. Phys., 6, 3131-3148, doi:10.5194/acp-6-3131-2006, 2006.

Bahadur, R., Praveen, P. S., Xu, Y. Y., and Ramanathan, V.: Solar absorption by elemental and brown carbon determined from spectral observations, P. Natl. Acad. Sci. USA, 109, 17366-17371, 2012.

Bahreini, R., Dunlea, E. J., Matthew, B. M., Simons, C., Docherty, K. S., DeCarlo, P. F., Jimenez, J. L., Brock, C. A., and Middlebrook, A. M.: Design and Operation of a Pressure-Controlled Inlet for Airborne Sampling with an Aerodynamic Aerosol Lens, Aerosol Sci. Tech., 42, 465-471, doi:10.1080/02786820802178514, 2008.

Bahreini, R., Ervens, B., Middlebrook, A. M., Warneke, C., de Gouw, J. A., DeCarlo, P. F., Jimenez, J. L., Brock, C. A., Neuman, J. A., Ryerson, T. B., Stark, H., Atlas, E., Brioude, J., Fried, A., Holloway, J. S., Peischl, J., Richter, D., Walega, J., Weibring, P., Wollny, A. G., and Fehsenfeld, F. C.: Organic aerosol formation in urban and industrial plumes near Houston and Dallas, Texas, J. Geophys. Res.-Atmos., 114, D09206, doi:10.1029/2008JD011493, 2009.

Barth, M. C., Cantrell, C. A., Brune, W. H., Rutledge, S. A., Crawford, J. H., Huntrieser, H., Carey, L. D., MacGorman, D., Weisman, D., Pickering, K. E., Bruning, E., Anderson, B., Apel, E., Biggerstaff, M., Campos, T., Campuzano-Jost, P., Cohen, R., Crounse, J., Day, D. A., Diskin, G., Flocke, F., Fried, A., Garland, C., Heikes, B., Honomichl, S., Hornbrook, R., Huey, L. G., Jimenez, J. L., Lang, T., Lichtenstern, M., Mikoviny, T., Nault, B., O’Sullivan, D., Pan, L. L., Peischl, J., Pollack, I., Richter, D., Riemer, D., Ryerson, T., Schlager, H., St. Clair, J., Walega, J., Weibring, P., Weinheimer, A., Wennberg, P., Wisthaler, A., Wooldridge, P. J., and Ziegler, C.: The Deep Convective Clouds and Chemistry (DC3) Field Campaign, Bull. Am. Meteorol. Soc., doi:10.1175/BAMS-D-13-00290.1, online first, 2014.

Baumgardner, D., Popovicheva, O., Allan, J., Bernardoni, V., Cao, J., Cavalli, F., Cozic, J., Diapouli, E., Eleftheriadis, K., Genberg, P. J., Gonzalez, C., Gysel, M., John, A., Kirchstetter, T. W., Kuhlbusch, T. A. J., Laborde, M., Lack, D., Müller, T., Niessner, R., Petzold, A., Piazzalunga, A., Putaud, J. P., Schwarz, J., Sheridan, P., Subramanian, R., Swietlicki, E., Valli, G., Vecchi, R., and
Viana, M.: Soot reference materials for instrument calibration and intercomparisons: a workshop summary with recommendations, Atmos. Meas. Tech., 5, 1869-1887, doi:10.5194/amt-51869-2012, 2012.

Bond, T. C. and Bergstrom, R. W.: Light absorption by carbonaceous particles: an investigative review, Aerosol Sci. Tech., 40, 27-67, 2006.

Bond, T. C., Anderson, T. L., and Campbell, D.: Calibration and intercomparison of filter-based measurements of visible light absorption by aerosols, Aerosol Sci. Tech., 30, 582-600, 1999.

Bond, T. C., Habib, G., and Bergstrom, R. W.: Limitations in the enhancement of visible light absorption due to mixing state, J. Geophys. Res., 111, D20211, doi:10.1029/2006JD007315, 2006.

Bond, T. C., Doherty, S. J., Fahey, D. W., Forster, P. M., Berntsen, T., DeAngelo, B. J., Flanner, M. G., Ghan, S., Kärcher, B., Koch, D., Kinne, S., Kondo, Y., Quinn, P. K., Sarofim, M. C., Schultz, M. G., Schulz, M., Venkataraman, C., Zhang, H., Zhang, S., Bellouin, N., Guttikunda, S. K., Hopke, P. K., Jacobson, M. Z., Kaiser, J. W., Klimont, Z., Lohmann, U., Schwarz, J. P., Shindell, D., Storelvmo, T., Warren, S. G., and Zender, C. S.: Bounding the role of black carbon in the climate system: A scientific assessment, J. Geophys. Res. Atmos., 118, 5380-5552, doi:10.1002/jgrd.50171, 2013.

Bush, B. and Valero, F. P. J.: Surface aerosol radiative forcing at Gosan during the ACE-Asia campaign, J. Geophys. Res., 108, 8660, doi:10.1029/2002JD003233, 2003.

Cappa, C. D., Onasch, T. B., Massoli, P., Worsnop, D. R., Bates,T. S., Cross, E. S., Davidovits, P., Hakala, J., Hayden, K. L., Jobson, B. T., Kolesar, K. R., Lack, D. A., Lerner, B. M., Li, S. M., Mellon, D., Nuaaman, I., Olfert, J. S., Petaja, T., Quinn, P. K., Song, C., Subramanian, R., Williams, E. J., and Zaveri, R. A.: Radiative absorption enhancements due to the mixing state of atmospheric black carbon, Science, 337, 1078-1081, 2012.

Carrico, C. M., Bergin, M. H., Xu, J., Baumann, K., and Maring, H.: Urban aerosol radiative properties: measurements during the 1999 Atlanta supersite experiment, J. Geophys. Res.-Atmos., 108, 8422, doi:10.1029/2001JD001222, 2003.

Chan, T. W., Brook, J. R., Smallwood, G. J., and Lu, G.: Time-resolved measurements of black carbon light absorption enhancement in urban and near-urban locations of southern Ontario, Canada, Atmos. Chem. Phys., 11, 10407-10432, doi:10.5194/acp-11-10407-2011, 2011.

Chen, Y. and Bond, T. C.: Light absorption by organic carbon from wood combustion, Atmos. Chem. Phys., 10, 1773-1787, doi:10.5194/acp-10-1773-2010, 2010.

Cheng, Y., He, K.-B., Du, Z.-H., Engling, G., Liu, J.-M., Ma, Y.-L., Zheng, M., and Weber, R. J.: The characteristics of brown carbon aerosol during winter in Beijing, in preparation, 2015.

Chung, C. E., Ramanathan, V., and Decremer, D.: Observationally constrained estimates of carbonaceous aerosol radiative forcing, P. Natl. Acad. Sci. USA, 109, 11624-11629, 2012.

Clarke, A., McNaughton, C., Kapustin, V., Shinozuka, Y., Howell, S., Dibb, J., Zhou, J., Anderson, B., Brekhovskikh, V., Turner, H., and Pinkerton, M.: Biomass burning and pollution aerosol over North America: organic components and their influence on spectral optical properties and humidification response, J. Geophys. Res., 112, D12S18, doi:10.1029/2006JD007777, 2007.

DeCarlo, P. F., Kimmel, J. R., Trimborn, A., Northway, M. J., Jayne, J. T., Aiken, A. C., Gonin, M., Fuhrer, K., Horvath, T., Docherty, 
K. S., Worsnop, D. R., and Jimenez, J. L.: Field-deployable, high-resolution, time-of-flight aerosol mass spectrometer, Anal. Chem., 78, 8281-8289, 2006.

de Gouw, J. A., Cooper, O. R., Warneke, C., Hudson, P. K., Fehsenfeld, F. C., Holloway, J. S., Hübler, G., Nicks Jr., D. K., Nowak, J. B., Parrish, D. D., Ryerson, T. B., Atlas, E. L., Donnelly, S. G., Schauer, S. M., Stroud, V., Johnson, K., Carmichael, G. R., and Streets, D. G.: Chemical composition of air masses transported from Asia to the US West Coast during ITCT 2K2: fossil fuel combustion vs. biomass-burning signatures, J. Geophys. Res., 109, D23S20, doi:10.1029/2003JD004202, 2004.

de Haan, D. O., Corrigan, A. L., Smith, K. W., Stroik, D. R., Turley, J. J., Lee, F. E., Tolbert, M. A., Jimenez, J. L., Cordova, K. E., and Ferrell, G. R.: Secondary organic aerosol-forming reactions of glyoxal with amino acids, Environ. Sci. Techol., 43, 28182824, 2009.

Desyaterik, Y., Sun, Y., Shen, X., Lee, T., Wang, X., Wang, T., and Collett Jr., J. L.: Speciation of "brown" carbon in cloud water impacted by agricultural biomass burning in eastern China, J. Geophys. Res.-Atmos., 118, 7389-7399, doi:10.1002/jgrd.50561, 2013.

Dunlea, E. J., DeCarlo, P. F., Aiken, A. C., Kimmel, J. R., Peltier, R. E., Weber, R. J., Tomlinson, J., Collins, D. R., Shinozuka, Y., McNaughton, C. S., Howell, S. G., Clarke, A. D., Emmons, L. K., Apel, E. C., Pfister, G. G., van Donkelaar, A., Martin, R. V., Millet, D. B., Heald, C. L., and Jimenez, J. L.: Evolution of Asian aerosols during transpacific transport in INTEX-B, Atmos. Chem. Phys., 9, 7257-7287, doi:10.5194/acp-9-7257-2009, 2009.

Feng, Y., Ramanathan, V., and Kotamarthi, V. R.: Brown carbon: a significant atmospheric absorber of solar radiation?, Atmos. Chem. Phys., 13, 8607-8621, doi:10.5194/acp-13-8607-2013, 2013.

Forrister, H., Liu, J., Scheuer, E., Dibb, J., Ziemba, L., Thornhill, K. L., Anderson, B., Diskin, G., Perring, A. E., Schwarz, J. P., Campuzano-Jost, P., Day, D. A., Palm, B. B., Jimenez, J. L., Nenes, A., and Weber, R. J.: Evolution of Brown Carbon in Wildfire Plumes, Geophys. Res. Lett., 42, 4623-4630, doi:10.1002/2015GL063897, 2015.

Gyawali, M., Arnott, W. P., Lewis, K., and Moosmüller, H.: In situ aerosol optics in Reno, NV, USA during and after the summer 2008 California wildfires and the influence of absorbing and non-absorbing organic coatings on spectral light absorption, Atmos. Chem. Phys., 9, 8007-8015, doi:10.5194/acp-9-8007-2009, 2009.

Hecobian, A., Zhang, X., Zheng, M., Frank, N., Edgerton, E. S., and Weber, R. J.: Water-Soluble Organic Aerosol material and the light-absorption characteristics of aqueous extracts measured over the Southeastern United States, Atmos. Chem. Phys., 10, 5965-5977, doi:10.5194/acp-10-5965-2010, 2010.

Hoffer, A., Gelencsér, A., Guyon, P., Kiss, G., Schmid, O., Frank, G. P., Artaxo, P., and Andreae, M. O.: Optical properties of humic-like substances (HULIS) in biomass-burning aerosols, Atmos. Chem. Phys., 6, 3563-3570, doi:10.5194/acp-6-3563-2006, 2006.

IPCC: Climate Change: The Physical Science Basis, Contribution of Working Group I to the UN IPCC's 5th Assessment Report, Cambridge University Press, New York, USA, 2013.
Kieber, R. J., Whitehead, R. F., Reid, S. N., Willey, J. D., and Seaton, P. J.: Chromophoric dissolved organic matter (CDOM) in rainwater, southeastern North Carolina, USA, J. Atmos. Chem., 54, 21-41, 2006.

Kirchstetter, T. W. and Thatcher, T. L.: Contribution of organic carbon to wood smoke particulate matter absorption of solar radiation, Atmos. Chem. Phys., 12, 6067-6072, doi:10.5194/acp-126067-2012, 2012.

Kirchstetter, T. W., Novakov, T., and Hobbs, P. V.: Evidence that the spectral dependence of light absorption by aerosols is aected by organic carbon, J. Geophys. Res., 109, D21208, doi:10.1029/2004JD004999, 2004.

Koch, D., Bond, T. C., Streets, D., Unger, N., and van der Werf, G. R.: Global impacts of aerosols from particular source regions and sectors, J. Geophys. Res., 112, D02205: doi:10.1029/2005JD007024, 2007.

Lack, D. A. and Cappa, C. D.: Impact of brown and clear carbon on light absorption enhancement, single scatter albedo and absorption wavelength dependence of black carbon, Atmos. Chem. Phys., 10, 4207-4220, doi:10.5194/acp-10-4207-2010, 2010.

Lack, D. A. and Langridge, J. M.: On the attribution of black and brown carbon light absorption using the Ångström exponent, Atmos. Chem. Phys., 13, 10535-10543, doi:10.5194/acp13-10535-2013, 2013.

Lack, D. A., Cappa, C. D., Covert, D. S., Baynard, T., Massoli, P., Sierau, B., Bates, T. S., Quinn, P. K., Lovejoy, E. R., and Ravishankara, A. R.: Bias in filter-based aerosol light absorption measurements due to organic aerosol loading: evidence from ambient measurements, Aerosol Sci. Tech., 42, 1033-1041, 2008.

Lack, D. A., Langridge, J. M., Bahreini, R., Cappa, C. D., Middlebrook, A. M., and Schwarz, J. P.: Brown carbon and internal mixing in biomass burning particles, P. Natl. Acad. Sci. USA, 109, 14802-14807, doi:10.1073/pnas.1206575109, 2012.

Lack, D. A., Bahreini, R., Langridge, J. M., Gilman, J. B., and Middlebrook, A. M.: Brown carbon absorption linked to organic mass tracers in biomass burning particles, Atmos. Chem. Phys., 13, 2415-2422, doi:10.5194/acp-13-2415-2013, 2013.

Lee, H. J., Aiona, P. K., Laskin, A., Laskin, J., and Nizkorodov, S. A.: Effect of solar radiation on the optical properties and molecular composition of laboratory proxies of atmospheric brown carbon, Environ. Sci. Technol., 48, 10217-10226, 2014.

Limbeck, A., Kulmala, M., and Puxbaum, H.: Secondary organic aerosol formation in the atmosphere via heterogeneous reaction of gaseous isoprene on acidic particles, Geophys. Res. Lett., 30, 1996, doi:10.1029/2003GL017738, 2003.

Lin, Y.-H., Budisulistiorini, S. H., Chu, K., Siejack, R. A., Zhang, H., Riva, M., Zhang, Z., Gold, A., Kautzman, K. E., and Surratt, J. D.: Light-Absorbing Oligomer Formation in Secondary Organic Aerosol from Reactive Uptake of Isoprene Epoxydiols, Environ. Sci. Technol., 48, 12012-12021, doi:10.1021/es503142b, 2014.

Liu, D., Taylor, J. W., Young, D. E., Flynn, M. J., Coe, H., and Allan, J. D.: The effect of complex black carbon microphysics on the determination of the optical properties of brown carbon, Geophys. Res. Lett., 42, 2014GL062443, doi:10.1002/2014GL062443, 2015.

Liu, J., Bergin, M., Guo, H., King, L., Kotra, N., Edgerton, E., and Weber, R. J.: Size-resolved measurements of brown carbon in water and methanol extracts and estimates of their contribution 
to ambient fine-particle light absorption, Atmos. Chem. Phys., 13, 12389-12404, doi:10.5194/acp-13-12389-2013, 2013.

Liu, J., Scheuer, E., Dibb, J. E., Ziemba, L. D., Thornhill, K. L., Anderson, B. E., Wisthaler, A., Mikoviny, T., Devi, J. J., Bergin, M., and Weber, R. J.: Brown cabon in the continential troposphere, Geophys. Res. Lett., 41, 2191-2195, doi:10.1002/2013GL058976, 2014.

Lukacs, H., Gelencser, A., Hammer, S., Puxbaum, H., Pio, C., Legrand, M., Kasper-Giebl, A., Handler, M., Limbeck, A., Simpson, D., and Preunkert, S.: Seasonal trends and possible sources of brown carbon based on 2 year aerosol measurements at six sites in Europe, J. Geophys. Res., 112, D23S18 doi:10.1029/2006JD008151, 2007.

McMeeking, G. R., Kreidenweis, S. M., Carrico, C. M., Lee, T., Collett Jr., J. L., and Malm, W. C.: Observations of smokeinfluenced aerosol during the Yosemite Aerosol Characterization Study: Size distributions and chemical composition, J. Geophys. Res., 110, D09206, doi:10.1029/2004JD005389, 2005.

McNaughton, C. S., Clarke, A. D., Howell, S. G., Pinkerton, M., Anderson, B., Thornhill, L., Hudgins, C., Winstead, E., Dibb, J. E., Scheuer, E., and Maring, H.: Results from the DC-8 inlet characterization experiment (DICE): airborne vs. surface sampling of mineral dust and sea salt aerosols, Aerosol Sci. Tech., 41, 136-159, 2007.

Middlebrook, A. M., Bahreini, R., Jimenez, J. L., and Canagaratna, M. R.: Evaluation of Composition-Dependent Collection Efficiencies for the Aerodyne Aerosol Mass Spectrometer using Field Data, Aerosol Sci. Tech., 46, 258-271, doi:10.1080/02786826.2011.620041, 2011.

Mohr, C., Lopez-Hilfiker, F. D., Zotter, P., Prévôt, A. S. H., Xu, L., Ng, N. L., Herndon, S. C., Williams, L. R., Franklin, J. P., Zahniser, M. S., Worsnop, D. R., Knighton, W. B., Aiken, A. C., Gorkowski, K. J., Dubey, M. K., Allan, J. D., Thornton, J. A.: Contribution of nitrated phenols to wood burning brown carbon light absorption in Detling, UK during winter time, Environ. Sci. Technol., 47, 6316-6324, doi:10.1021/es400683v, 2013.

Moosmüller, H., Chakrabarty, R. K., Ehlers, K. M., and Arnott, W. P.: Absorption Ångström coefficient, brown carbon, and aerosols: basic concepts, bulk matter, and spherical particles, Atmos. Chem. Phys., 11, 1217-1225, doi:10.5194/acp-11-12172011, 2011.

Myhre, G., Hoyle, C. R., Berglen, T. F., Johnson, B. T., and Haywood, J. M.: Modeling of the solar radiative impact of biomass burning aerosols during the Dust and Biomassburning Experiment (DABEX), J. Geophys. Res., 113, D00C16, doi:10.1029/2008JD009857, 2008.

Park, R. J., Kim, M. J., Jeong, J. I., Yooun, D., and Kim, S.: A contribution of brown carbon aerosol to the aerosol light absorption and its radiative forcing in East Asia, Atmos. Environ., 44, 14141421,2010

Petzold, A., Schloesser, H., Sheridan, P. J., Arnott, W. P., Ogren, J. A., and Virkkula, A.: Evaluation of multi-angle absorption photometry for measuring aerosol light absorption, Aerosol Sci. Tech., 39, 40-51, 2005.

Saleh, R., Hennigan, C. J., McMeeking, G. R., Chuang, W. K., Robinson, E. S., Coe, H., Donahue, N. M., and Robinson, A. L.: Absorptivity of brown carbon in fresh and photo-chemically aged biomass-burning emissions, Atmos. Chem. Phys., 13, 76837693, doi:10.5194/acp-13-7683-2013, 2013.
Saleh, R., Robinson, E. S., Tkacik, D. S., Ahern, A. T., Liu, S., Aiken, A. C., Sullivan, R. C., Presto, A. A., Dubey, M. K., Yokelson, R. J., Donahue, N. M., and Robinson, A. L.: Brownness of organics in aerosols from biomass burning linked to their black carbon content, Nat. Geosci., 7, 647-650, doi:10.1038/ngeo2220, 2014.

Samset, B. H. and Myhre, G.: Vertical dependence of black carbon, sulphate and biomass burning aerosol radiative forcing, Geophys. Res. Lett., 38, L24802, doi:10.1029/2011GL049697, 2011.

Sandradewi, J., Prévôt, A. S. H., Alfarra, M. R., Szidat, S., Wehrli, M. N., Ruff, M., Weimer, S., Lanz, V. A., Weingartner, E., Perron, N., Caseiro, A., Kasper-Giebl, A., Puxbaum, H., Wacker, L., and Baltensperger, U.: Comparison of several wood smoke markers and source apportionment methods for wood burning particulate mass, Atmos. Chem. Phys. Discuss., 8, 8091-8118, doi:10.5194/acpd-8-8091-2008, 2008.

Sareen, N., Schwier, A. N., Shapiro, E. L., Mitroo, D., and McNeill, V. F.: Secondary organic material formed by methylglyoxal in aqueous aerosol mimics, Atmos. Chem. Phys., 10, 997-1016, doi:10.5194/acp-10-997-2010, 2010.

Schnaiter, M., Schmid, O., Petzold, A., Fritzsche, L., Klein, K. F., Andreae, M. O., Helas, G., Thielmann, A., Gimmler, M., Mohler, O. M., Linke, C., and Schurath, U.: Measurement of wavelength resolved light absorption by aerosols utilizing a UV-VIS extinction cell, Aerosol Sci. Tech., 39, 249-260, 2005.

Schwarz, J. P., Spackman, J. R., Fahey, D. W., Gao, R. S., Lohmann, U., Stier, P., Watts, L. A., Thomson, D. S., Lack, D. A., Pfister, L., Mahoney, M. J., Baumgardner, D., Wilson, J. C., and Reeves, J. M.: Coatings and their enhancement of black carbon light absorption in the tropical atmosphere, J. Geophys. Res., 113, D03203, doi:10.1029/2007JD009042, 2008.

Slowik, J. G., Cross, E. S., Han, J. H., Davidovits, P., Onasch, T. B., Jayne, J. T., Williams, L. R., Canagaratna, M. R., Worsnop, D. R., Chakrabarty, R. K., Moosmüller, H., Arnott, W. P., Schwarz, J. P., Gao, R. S., Fahey, D. W., Kok, G. L., and Petzold, A.: An inter-comparison of instruments measuring black carbon content of soot particles, Aerosol Sci. Tech., 41, 295-314, doi:10.1080/02786820701197078, 2007.

Sueper: available at: http://cires.colorado.edu/jimenez-group/wiki/ index.php/ToF-AMS_Analysis_Software, 2015.

Sun, H. L., Biedermann, L., and Bond, T. C.: Color of brown carbon: a model for ultraviolet and visible light absorption by organic carbon aerosol, Geophys. Res. Lett., 34, L17813, doi:10.1029/2007GL029797, 2007

Virkkula, A.: Correction of the calibration of the 3-wavelength particle soot absorption photometer (3 PSAP), Aerosol Sci. Tech. 44, 706-712, 2010.

Washenfelder, R. A., Attwood, A. R., Brock, C. A., Guo, H., Xu, L., Weber, R. J., Ng, N. L., Allen, H. M., Ayres, W. R., Baumann, K., Cohen, R. C., Draper, D. C., Duffey, K. C., Edgerton, E., Fry, J. L., Hu, W. W., Jimenez, J. L., Palm, B. B., Romer, P., Stone, E. A., Wooldridge, P. J., and Brown, S. S.: Biomass burning dominates brown carbon absorption in the rural southeastern United States, Geophys. Res. Lett., 42, 653-664, doi:10.1002/2014GL062444, 2015.

Yang, M., Howell, S. G., Zhuang, J., and Huebert, B. J.: Attribution of aerosol light absorption to black carbon, brown carbon, and dust in China - interpretations of atmospheric measure- 
ments during EAST-AIRE, Atmos. Chem. Phys., 9, 2035-2050, doi:10.5194/acp-9-2035-2009, 2009.

Zarzana, K. J., Haan, D. O. D., Freedman, M. A., Hasenkopf, C. A., and Tolbert, M. A.: Optical properties of the products of $\alpha$ dicarbonyl and amine reactions in simulated cloud droplets, Environ. Sci. Technol., 46, 4845-4851, 2012.

Zhang, X., Lin, Y.-H., Surratt, J. D., Zotter, P., Prevot, A. S. H., and Weber, R. J.: Light-absorbing soluble organic aerosol in Los Angeles and Atlanta: a contrast in secondary organic aerosol, Geophys. Res. Lett., 38, L21810, doi:10.1029/2011GL049385, 2011.

Zhang, X., Lin, Y.-H., Surratt, J. D., and Weber, R. J.: Sources, composition and absorption Angström exponent of light-absorbing organic components in aerosol extracts from the Los Angeles Basin, Environ. Sci. Technol., 47, 3685-3693, 2013.
Zhang, X. L., Liu, J. M., Parker, E. T., Hayes, P. L., Jimenez, J. L., de Gouw, J. A., Flynn, J. H., Grossberg, N., Lefer, B. L., and Weber, R. J.: On the gas-particle partitioning of soluble organic aerosol in two urban atmospheres with contrasting emissions, 1, bulk water-soluble organic carbon, J. Geophys. Res.-Atmos., 117, D00V16, doi:10.1029/2012JD017908, 2012.

Zhong, M. and Jang, M.: Dynamic light absorption of biomassburning organic carbon photochemically aged under natural sunlight, Atmos. Chem. Phys., 14, 1517-1525, doi:10.5194/acp-141517-2014, 2014. 